\title{
Effects of three clipping managements on growth and production of a Kentucky bluegrass-clover sward
}

\author{
Beverly Ellen Sedon \\ West Virginia University
}

Follow this and additional works at: https://researchrepository.wvu.edu/etd

\section{Recommended Citation}

Sedon, Beverly Ellen, "Effects of three clipping managements on growth and production of a Kentucky bluegrass-clover sward" (2001). Graduate Theses, Dissertations, and Problem Reports. 1279.

https://researchrepository.wvu.edu/etd/1279

This Thesis is protected by copyright and/or related rights. It has been brought to you by the The Research Repository @ WVU with permission from the rights-holder(s). You are free to use this Thesis in any way that is permitted by the copyright and related rights legislation that applies to your use. For other uses you must obtain permission from the rights-holder(s) directly, unless additional rights are indicated by a Creative Commons license in the record and/ or on the work itself. This Thesis has been accepted for inclusion in WVU Graduate Theses, Dissertations, and Problem Reports collection by an authorized administrator of The Research Repository @ WVU. For more information, please contact researchrepository@mail.wvu.edu. 


\title{
Effects of Three Clipping Managements on Growth and Production of a Kentucky Bluegrass-Clover Sward
}

\author{
Beverly Sedon
}

\begin{abstract}
A Thesis
Submitted to the

College of Agriculture, Forestry, and Consumer Sciences

at West Virginia University

in partial fulfillment of the requirements for the degree of
\end{abstract}

Master of Science
in

Dr. William B. Bryan, Chair

Dr. John A. Balasko

Dr. Edward C. Prigge

Dr. Stanislaw Tajchman

Department of Plant and Soil Sciences

Morgantown, WV

2001

Keywords: Kentucky bluegrass, Leaf extension rate, Cutting managements 


\section{Abstract \\ Effects of Three Clipping Managements on Growth and Production of a Kentucky Bluegrass-Clover Sward}

\section{Beverly Sedon}

The effect of three clipping managements on the growth and production of Kentucky bluegrass was investigated at the West Virginia University Livestock Farm. Herbage accumulation, botanical composition, leaf extension rate (LER), leaf appearance rate (LAR), and tiller density were observed. The sward was clipped to three heights, 2.5, 5.1 , and $7.6 \mathrm{~cm}$, from a recovery growth of 13 to $15 \mathrm{~cm}$. Nitrogen was applied in split applications twice a year at three rates $\left(0,80\right.$, and $\left.160 \mathrm{~kg} \mathrm{~N} \mathrm{ha}^{-1}\right)$. Herbage accumulation and growth rates were higher in 2000 than 1999. Rainfall was higher in 2000 than in 1999. Low cut plots produced the most herbage. The proportion of legume increased from 1999 to 2000 and the highest proportion was in the low and high cut plots. Highest LER and LAR occurred in the spring and late summer/early fall. Tiller density was highest when nitrogen was applied. 


\section{Acknowledgments}

Thank you to Dr. William Bryan for all of your support and guidance. To my committee members, who have supported me in this study, thank you. Thanks to my family for supporting me throughout my college years. 
Abstract $\quad$ ii

Acknowledgments iii

Table of Contents iv

List of Tables

List of Figures vii

List of Symbols viii

Introduction 1

Literature Review $\quad 2$

Characteristics and growth of Kentucky bluegrass 2

Kentucky bluegrass and clover mixture $\quad 4$

Clipping and herbage accumulation 5

Leaf extension rate $\quad 6$

$\begin{array}{ll}\text { Objectives } & 7\end{array}$

$\begin{array}{ll}\text { Methods and Materials } & 7\end{array}$

$\begin{array}{lc}\text { Treatments } & 8\end{array}$

$\begin{array}{ll}\text { Botanical composition } & 9\end{array}$

$\begin{array}{ll}\text { Herbage accumulation } & 9\end{array}$

$\begin{array}{ll}\text { Leaf extension rate } & 10\end{array}$

$\begin{array}{ll}\text { Leaf appearance rate } & 10\end{array}$

$\begin{array}{ll}\text { Tiller density } & 10\end{array}$

Results 12

Weather 12

$\begin{array}{ll}\text { Soil } & 12\end{array}$

$\begin{array}{ll}\text { Herbage accumulation } & 16\end{array}$

Botanical composition $\quad 20$

$\begin{array}{ll}\text { Leaf extension rate } & 23\end{array}$

$\begin{array}{ll}\text { Leaf appearance rate } & 27\end{array}$

Tiller density $\quad 29$

$\begin{array}{ll}\text { Discussion } & 31\end{array}$ 
Conclusion

References

Appendices

38

Vita 


\section{$\underline{\text { List of Tables }}$}

Table $1 \quad$ Dates cutting treatments were harvested in 1999 and 2000 and rainfall received between each harvest

Table 2 Soil analysis for each year

Table 3 Effect of cutting height, nitrogen treatment, and year on annual herbage accumulation

Table 4 Annual herbage accumulation and per harvest for cutting height, nitrogen treatment, and year 


\section{List of Figures}

$\begin{array}{lll}\text { Figure } 1 & \text { Average temperatures for } 1999 \text { and } 2000 & 14\end{array}$

$\begin{array}{lll}\text { Figure } 2 & \text { Average rainfall for } 1999 \text { and } 2000\end{array}$

Figure 3 Total herbage accumulation for each cutting height for 1999 and 2000

Figure 4 Total herbage accumulation in 1999 for each cutting

height and nitrogen treatment

Figure 5 Total herbage accumulation for each cutting height and growing period in $2000 \quad 21$

Figure $6 \quad$ Botanical composition at each cutting height in $1999 \quad 21$

Figure $7 \quad$ Botanical composition for 1999 and $2000 \quad 22$

Figure $8 \quad$ Botanical composition for each growing period 22

Figure 9 Visual estimate of clover at each cutting height and nitrogen treatment in $2000 \quad 24$

Figure 10 Leaf extension rate for each growing period in 1999 and $2000 \quad 24$

Figure 11 Leaf extension rate for growing period at each nitrogen treatment in 1999

Figure 12 Leaf extension rate in 1999 at each growing period and cutting height

Figure 13 Leaf extension rate in 2000 at each growing period and cutting height

Figure 14 Leaf extension rate for cutting height and nitrogen treatment in 1999

Figure 15 Leaf extension rate for growing period and leaf $\begin{array}{ll}\text { category } & 28\end{array}$

Figure $16 \quad$ Leaf appearance rate for each year and growing period 28

Figure 17 Leaf appearance rate for year and cutting height 30

Figure 18 Leaf appearance rate for growing period and cutting height in $2000 \quad 30$ 


\section{$\underline{\text { List of Symbols }}$}

Leaf appearance rate

LAR

Leaf area index

LAI

Leaf extension rate

LER

West Virginia University

WVU 


\section{Introduction}

West Virginia can be recognized by the wooded hills, deep valleys, and rolling plateaus of the Appalachian Mountains. Elevation ranges from $1482 \mathrm{~m}$ at Spruce Knob in the Potomac Highlands to $73 \mathrm{~m}$ at the Potomac River in Harpers Ferry. Because of the state's hilly terrain and deep valleys, large-scale crop production is difficult, although, many good quality pastures along the wide valleys and on hillsides are favorable for sheep and cattle production. Due to economic pressures, the beef and sheep industries rely on pastures. Finding low input managements to provide sustainable pastures is important for the farmer's business.

Kentucky bluegrass (Poa pratensis L.) and clover are common in much of West Virginia's pastures and turf. Kentucky bluegrass is a low growing grass that produces underground rhizomes that help reduce soil erosion on many hillsides as well as supplying forage to animals. Maintaining desired grass and clover populations within the pasture is important in making grasslands productive. Pasture production and composition are influenced by defoliation management and fertilizer application. The farmer can control the sward height at which defoliation occurs and how much herbage is removed. The major nutrient limitations in pastures are nitrogen and phosphorus. Legumes contribute nitrogen to the pasture, helping to make inputs low. When nitrogen application is made, it is often fast acting, and its influence on growth does not last long. The primary use of nitrogen fertilization is to increase production. However, since Kentucky bluegrass grows most during spring and then deceases dramatically, the possible use of nitrogen to increase its production at times of lower growth is important. In this experiment nitrogen was applied in the late spring (June) in order to extend the growing season into summer. Nitrogen was also added in the late summer (August/September) to enhance fall and spring growth.

Observing and measuring leaf extension rate, leaf appearance rate and tiller numbers in response to managements over the growing season helps identify the rate of growth for pastures. Little research has been published on LER, LAR, and tiller numbers as affected by defoliation management and nitrogen fertilization of Kentucky bluegrass. For this reason, an experiment was designed to study the effects of cutting management and nitrogen treatment on these factors. 


\section{Literature Review}

\section{Characteristics and growth of Kentucky bluegrass}

Kentucky bluegrass is native to northern Eurasia and the mountains of Algeria and Morocco, and it can be found in the northern regions of North America (11). Kentucky bluegrass was introduced after $1500 \mathrm{AD}$ to the eastern United States from England in forage used for cattle and dispersed from the sweepings of boats. It has since made its way across the Northern Hemisphere $(3,17)$. This cool-season grass grows well on moist soils in cool, humid climates. As a perennial, its wide distribution across the northern US is very important in pastures and turf. It is preferred because of its winter hardiness and ability to tolerate frequent harvest.

The foliage can be recognized by folded leaves in the bud shoot and boat shaped leaf tips. The blades are 1 to $6 \mathrm{~mm}$ wide and 5 to $15 \mathrm{~cm}$ long. During flowering, it displays a pyramidal panicle with slender branches in whorls (8). It reproduces apomictically and can spread by means of rhizomes creating a dense sod. Kentucky bluegrass has become adapted to various habitats by hybridization.

Vegetative shoots of Kentucky bluegrass produce tillers, intravaginal shoots that push their way above the enclosing sheaths, and rhizomes or underground stems. These underground stems can emerge from the soil to form new plants at a distance from the parent plant. Kentucky bluegrass can also proliferate by seed.

Madison (15) noted that Kentucky bluegrass shoots have a life of about 4 to 5 months and can produce 14 to 20 leaves. He also noted that, when leaf blades were long $(13$ to $30 \mathrm{~cm}$ ), the number of plants with only one tiller was greater than the number of plants with multiple tillers, because more energy was put into producing longer leaves than into producing more tillers. When leaf blades were short $(3$ to $12 \mathrm{~cm}$ ), the number of plants with multiple tillers was substantially higher than the number with only one tiller. Harrison (14) showed that when no nitrogen was applied, Kentucky bluegrass produced short and broad leaves, whereas when nitrogen was added, the leaves produced were long and narrow.

Tillering and rhizome production are noted to be reciprocal. When tillers are formed, rhizome production is less and vice versa (15). Production of tillers is most 
common in the early spring and late fall when temperatures are cool, 1.7 to $10^{\circ} \mathrm{C}(11)$. Tillers formed in late fall that are vigorous will flower in the spring. If the flower stalks are removed, tillering is induced (15). Rhizome production takes place mainly in the summer when temperatures range from 15.6 to $21.1^{\circ} \mathrm{C}$. Both tiller and rhizome production can be noticed during late spring and early fall when temperatures are around 10.0 to $15.6^{\circ} \mathrm{C}$. Below $1.7^{\circ} \mathrm{C}$, neither tillers nor rhizomes are produced (11). Harrison (14) found that during summer, when days are long, more rhizomes are produced and less above ground or top growth is produced than on short days when more top growth and fewer rhizomes are produced. Evans and Watkins (12) reported similar results, finding that two-thirds more shoots were produced under short than under long days. They also noted that shoot growth under long days was more upright whereas shoot growth under short days was more decumbent. More decumbent growth on short days in winter allows the leaves to open up and receive more light for photosynthesis.

The slowing of tiller production or top growth during hot summers is often referred to as a "summer slump" (14). A study by Harrison (14) looked at Kentucky bluegrass grown in a greenhouse during the summer (July and August) at three different temperatures, $15.6,26.7$, and $37.8^{\circ} \mathrm{C}$, with and without nitrogen application, cut to $2.5 \mathrm{~cm}$ every ten days. He found that plants grown at $37.8^{\circ} \mathrm{C}$ with or without nitrogen grew very little, and most rhizome tips and roots died. Plants grown at $15.6^{\circ} \mathrm{C}$ had more top growth than those grown at $26.7^{\circ} \mathrm{C}$ with or without nitrogen. At $15.6^{\circ} \mathrm{C}$, plants that had no nitrogen applied had slightly less top growth and more root growth than those that were supplied with nitrogen. Those grown at $26.7^{\circ} \mathrm{C}$ without nitrogen had over twice as much top growth as the plants with nitrogen. Thus, if nitrogen is used, applications in the late spring or fall when temperatures are cool $\left(15.6^{\circ} \mathrm{C}\right)$ would be more effective than applications in the summer when temperatures are higher.

Baker and Younger (5) mentioned that fall management could influence spring production by affecting the density of tillers. Harrison (14) found that the application of nitrogen in the fall, during short days, caused rhizomes to cease growth and emerge from the soil to form new shoots. When no nitrogen was applied, rhizomes continued growth and no new top growth occurred. Madison (15) explained that when nitrogen levels were low, plant root systems were larger in size and contained more carbohydrates in storage 
than at high nitrogen levels. When nitrogen levels were low and nitrogen was added, it was quickly taken up by the plant and combined with carbohydrates to form amino acids. Carbohydrate levels began to decrease, and the root systems decreased in size. Thus, when nitrogen is added at high rates, carbohydrate storage becomes low, and if the plant becomes temperature stressed, no reserves are left to maintain dormancy.

Timing of nitrogen application at different rates will have varying results. Applying high rates of nitrogen in April or May can cause the leaves to grow more since nitrogen is allocated to the leaves first. However, a high density of leaves can result in competition for light and lower photosynthetic efficiency. Applying high rates of nitrogen in the months of June, July, or August not only decreases root and rhizome growth but also attracts insects that may stress the plant. Insect attraction may be due to the high density and dark green color of the sward that does not occur under low nitrogen levels. During hot and humid conditions fungal growth may also inhibit growth. Applying nitrogen at low levels in the fall can increase tiller density and prevent winter injury when compared to applying higher rates (15).

\section{Kentucky bluegrass and clover mixture}

Kentucky bluegrass is most often found in a sward with white clover (Trifolium repens L.) and/or red clover (Trifolium pratense L.). The proportion of grass and clover can be affected by competition for light, space, moisture, and nutrients. Other factors such as day length, temperature, management practices, and disease can also alter the grass or clover's ability to compete. When moisture is limited, white clover is unable to compete because its roots are shallow, whereas, grass, with long roots, can penetrate the soil more deeply (19). Appadurai and Holmes (2) found that ryegrass and white clover proportions were affected more by soil moisture conditions than the height of clip. When conditions were dry, clover content was low. If the soil nitrogen was low, the grass was unable to compete with the clover. When clover was abundant, the grass competed poorly until it could benefit from the available nitrogen fixed by the clover. The grass, then, was able to compete, creating a dense sod and reducing the clover proportion.

Kentucky bluegrass has optimum growth in the early spring and late fall when temperatures are cool. During the summer, when Kentucky bluegrass growth slows due 
to warmer temperatures, white clover will compete much better if moisture is not limiting, because it has a higher optimum growth temperature than Kentucky bluegrass (19). Chapman (7) observed a decrease in leaf appearance rate of white clover during the winter and an increase in the spring when soil temperatures rose above $9^{\circ} \mathrm{C}$.

The clipping management of bluegrass-clover swards influences botanical composition over a period of time. A two-year study by Robinson and Sprague (19) showed that when a Kentucky bluegrass-white clover sward was closely clipped to $1.27 \mathrm{~cm}$ with ample time for recovery between clippings, it maintained a high percentage of white clover with less bluegrass. This result was compared with a more lenient clipping to no less than $5.08 \mathrm{~cm}$ that created a dense sod of Kentucky bluegrass with less white clover. Similar results were also found with a perennial ryegrass-white clover sward. In a three-year experiment, Acunap and Wilman (1) found that when the sward was clipped every four weeks from April to October, clover content was greatest for the 2 $\mathrm{cm}$ cut in the second and third years, and perennial ryegrass content was reduced as cutting heights were reduced from 10 to $2 \mathrm{~cm}$. In summary, as the cutting height is increased the proportion of white clover in the sward will decrease over time.

\section{Clippings and herbage accumulation}

Clipping management affects the physical structure of the canopy and can thus change the growth response. Kentucky bluegrass is often noted for being tolerant to low and frequent clipping. Madison (15) noted that managements such as mowing, fertilizing, and irrigation can affect the shape, size, and frequency of tiller and rhizome appearance. More shoots are produced when defoliation occurs than with no defoliation, either with or without applied nitrogen, throughout the growing season (11). Comparing fertilizer and no fertilizer, fertilized plots produced more shoots over the growing season. A study by Mortimer and Ahlgren (16) showed that Kentucky bluegrass requires a recovery period to maintain its tolerance to low grazing. Grass heights of 5.1 to $7.6 \mathrm{~cm}$ and 10.2 to $12.7 \mathrm{~cm}$ were compared when both were cut to ground level. Herbage accumulation was shown to be much higher when the grass was allowed to grow to 10.2 to $12.7 \mathrm{~cm}$. The 5.1 to

$7.6 \mathrm{~cm}$ treatment showed a reduction in herbage accumulation over time due to a reduction in food reserves in the rhizomes. They also compared grass heights of 10.2 to 
12.7 and 20.3 to $25.4 \mathrm{~cm}$, cut to ground level, to determine if an even longer recovery period would result in more herbage accumulation. The results showed that the grass allowed to grow to 20.3 to $25.4 \mathrm{~cm}$ had only a $5.3 \%$ higher herbage accumulation. They noted that this was due to light competition. By maintaining the grass at 10.2 to $12.7 \mathrm{~cm}$ rather than at 20.3 to $25.4 \mathrm{~cm}$, new emerging leaves were better able to capture sunlight, increasing photosynthetic activity of the tiller and hence, plant growth. Dovel (9) studied Kentucky bluegrass pastures that were cut three times per year to heights of 5, 10, and 15 $\mathrm{cm}$. He found that herbage accumulation decreased an average of 33\% as the height of clip increased, meaning less herbage was being removed as the height of clip increased. He noted that clipping to a height of $5 \mathrm{~cm}$ was not significantly low enough to slow regrowth and reduce herbage accumulation. Appadurai and Holmes (2) studied a ryegrass-white clover sward and found similar results to Dovel's study. The accumulation of ryegrass was higher in the plots that were closely clipped to $2.5 \mathrm{~cm}$ than the plots clipped to 6.4 to $7.6 \mathrm{~cm}$ over two years. They also found less difference in herbage accumulation between close and lax cuttings when conditions were dry than when conditions were wet. When conditions were wet, herbage accumulation was 20 to $41 \%$ higher than when conditions were dry. In a study by Bryan and Mills (6) on herbage accumulation of Kentucky bluegrass, herbage was 50\% higher in a year when conditions were not limited by soil moisture. The dry year received $15 \mathrm{~cm}$ less rainfall than the wet year and differences among the treatments were less than in the wet year.

\section{Leaf extension rate}

Leaf extension rate (LER) is defined as the rate at which a leaf blade extends in a given amount of time. The length of young leaves is measured until they are fully emerged. The distance between the tip of a new leaf and the point from where that leaf emerges from the sheath of the preceding leaf is recorded periodically to obtain a rate. Baker and Younger (5) found that LER is correlated with temperature. Using perennial ryegrass, they found that for every $1^{\circ} \mathrm{C}$ increase in soil temperature at $10 \mathrm{~cm}$ depth, leaf extension rate increased $0.4 \mathrm{~mm} \mathrm{~d}^{-1}$. They also noted that the rate of leaf extension in the spring was directly related to the amount of $\mathrm{N}$ applied the previous fall. As the amount of nitrogen $\left(0,200,400 \mathrm{~kg} \mathrm{~N} \mathrm{ha}^{-1}\right)$ increased the rate of leaf extension increased. Baker and 
Younger (4) in a different study also looked at how soil moisture influences the soil temperature and thus LER. They found that temperature increased more quickly in a dry well-drained soil, and thus increased LER, compared to saturated soils.

Very little information is available on the LER of Kentucky bluegrass. Ebdon and Petrovic (10) looked at 61 cultivars of Kentucky bluegrass in a greenhouse study. They separated them into low and high water use cultivars and imposed two clipping treatments, clipped to $45 \mathrm{~mm}$ or unclipped. The cultivars were fertilized monthly with $5 \mathrm{~g}$ $\mathrm{N} \mathrm{m}^{-2}$. They found that low water use cultivars had slower LER (4\% less in clipped plots and $12 \%$ less in unclipped plots) than the high water use cultivars.

\section{Objectives}

1. To determine the effects of three cutting managements and three nitrogen rates on herbage accumulation and botanical composition of a Kentucky bluegrass/clover pasture.

2. To measure leaf extension rate, leaf appearance rate, and tiller density of Kentucky bluegrass under three cutting managements and three nitrogen rates.

\section{Methods and Materials:}

The experiment was conducted at the West Virginia University (WVU) Livestock Farm in Morgantown, West Virginia 39.6N 79.9W on a pasture consisting primarily of Kentucky bluegrass and some white and red clover. As an extension of this experiment a psuedostem development study of Kentucky bluegrass was conducted at the WVU greenhouse, the results of which can be found in Appendix A. The soil type was Dormont silt loam (fine-loamy, mixed mesic ultic Hapludalfs) with a slope of 15 to $25 \%$ and a northwest aspect. The experiment was conducted during the growing seasons of 1999 (April to October) and 2000 (April to September). The experiment was a 3 x 3 factorial

with three cutting treatments and three nitrogen treatments. A randomized complete block design with four replications was used. Each replication was a block and contained nine 
plots (Appendix B). The plots were $4 \mathrm{~m}$ long and $2 \mathrm{~m}$ wide, with the length parallel to the slope (Appendix C). There was a border strip $0.53 \mathrm{~m}$ wide at both ends. The center strip, an area of $0.53 \mathrm{~m}$ wide by $2 \mathrm{~m}$ long to match the width of the lawn mower used to harvest, was randomly placed at either the top or the bottom of each plot located within the bordered area. This center strip was divided into five equal sections each $0.53 \mathrm{~m}$ wide by $0.4 \mathrm{~m}$ long. The other end of the plot, opposite the center strip area, was used for extracting soil cores.

\section{Treatments:}

The experiment was a $3 \times 3$ factorial with three cutting treatments and three nitrogen treatments within four blocks.

1. The grass was cut to the following three levels from a recovery growth of 12.7 to $15.2 \mathrm{~cm}$ :

- $2.5 \mathrm{~cm} \mathrm{low}$

- $5.1 \mathrm{~cm}$ medium

- $7.6 \mathrm{~cm}$ high

2. There were three nitrogen treatments in split applications:

- No nitrogen

- $80 \mathrm{~kg} \mathrm{ha}^{-1}$

- $160 \mathrm{~kg} \mathrm{ha}^{-1}$

The sward was initially mowed as close as possible to ground level $(1$ to $3 \mathrm{~cm}$ ) on 19 March 1999 using a five horse power push mower with a basket attachment. The clippings were removed. All large weeds were removed mechanically when they became visible. The height of the sward was measured using both a ruler and a plate meter in 1999 and only the plate meter in 2000 (18). The ruler and plate meter were used in the first year to develop a regression between ruler and plate heights. The plate meter was preferred for measuring the height of the sward because it was not subjective and considered a larger area $\left(46 \mathrm{~cm}^{2}\right)$. Two sward height measurements were taken from the center strip of each plot each week. The measurements were averaged for each plot. 
When three out of the four replications reached a recovery height between $12.7 \mathrm{~cm}$ and $15.2 \mathrm{~cm}$, the plots were mowed to the assigned treatment heights, and the clippings were removed.

Two applications of ammonium nitrate were applied each season at half the treatment rate. The first application was made in late spring (3 June 1999, and 2 June 2000). The second application was made in late summer (10 September 1999, and 30 August 2000).

Soil samples were collected on 28 November in 1999, and on 25 September in 2000. The sampling was done at two depths, 5.1 and $7.6 \mathrm{~cm}$, giving two final samples per plot. Six plugs, three from each side, were taken from the area adjacent to the center strip of each plot. Each sample was analyzed at the WVU soil-testing laboratory for $\mathrm{pH}$, available $\mathrm{P}, \mathrm{K}, \mathrm{Ca}$, and $\mathrm{Mg}$ (13).

Botanical composition was estimated by clipping one $15 \times 40 \mathrm{~cm}$ quadrat in a randomly chosen section of the center strip of each plot before harvesting. A different section was randomly chosen at every harvest. Samples were taken on the day of harvest, prior to mowing, and clipping height was according to treatment. The goal was to analyze the herbage being removed from each treatment. Each sample was separated by hand into four groups, grass, legume, weed, and senesced material. After hand separation botanical composition was estimated in two ways. The leaf area of each group was measured using a LiCor Model 3100 area meter. Then the samples were dried in a Fisher oven at $70^{\circ} \mathrm{C}$ for 48 hours and weighed. Botanical composition data were calculated for both leaf area and dry weight by dividing each individual component's leaf area or dry weight by the total leaf area or dry weight of the sample and multiplying that number by 100 . As the content of clover appeared to increase in the sward from 1999 to 2000, a visual estimate of the proportion of clover in each plot was made in June of 2000. Two visual estimates of clover from the northeast side of each plot were recorded, one visual estimate per person. The two estimates were then averaged.

Herbage accumulation was measured by cutting the center strip with a rotary lawn mower and collecting the herbage with a basket attachment. The remainder of the plot was cut with the same mower and herbage removed. The herbage from the center strip was weighed in the field. A sample, 3 to 4 handfuls, was taken, placed in a brown 
paper bag, brought back to the laboratory, and fresh weight recorded. The samples were dried in a $70^{\circ} \mathrm{C}$ oven for 48 hours and weighed. Herbage accumulation was calculated by dividing the sample dry weight by the sample fresh weight and multiplying that number by the total weight of the herbage harvested from the center strip. The dry weights of the botanical composition samples were added to the herbage mass because they were collected from the center strip area. Finally, herbage accumulation was calculated as $\mathrm{kg}$ $\mathrm{ha}^{-1}$. After May 2000, all the herbage collected from the center strip was dried and weighed.

Leaf extension rate (LER) was measured throughout the growing season by marking individual tillers. Two of the five sections in the center strip were randomly chosen and a tiller was marked in each. Tillers were chosen in the same section throughout the experiment. Individual tillers were selected by dropping a golf tee from approximately $61 \mathrm{~cm}$ above the chosen section. The closest Kentucky bluegrass tiller to the tip of the tee was marked. Marking was done by inserting a golf tee on each side of the tiller to clearly identify which one was being observed. Tees were placed in the soil pointing away from the plant to not disturb the root system. A flag was then inserted into the ground next to the tees to help identify the marked tiller. Flags were removed prior to clipping for botanical composition samples and then replaced after mowing. The same tillers were measured until their death, and then the Kentucky bluegrass tiller closest to the one that died was tagged. Uncut live leaves were measured for length once or twice a week from April to October in 1999 and from April to September in 2000. The distance between the tip of a new leaf and where the leaf emerged from the sheath of the preceding leaf was measured and divided by the time interval between measurements. As soon as a new leaf appeared, measurements were made on it and discontinued on the previous leaf since the older one had ceased to grow.

Leaf appearance rate (LAR) was calculated as the number of new leaves appearing on marked tillers divided by the time interval between LER measurements.

Tiller density was obtained from $26.4 \mathrm{~cm}^{2}$ cores taken from the side borders of each plot. Cores were taken to best visually represent the center strip canopy. In 1999, samples were taken in spring (27 May), late summer (23 September), and fall (25 October). In 2000, samples were taken in early-spring (14 April), mid-summer (6 July), 
and early fall (18 September). Tillers were carefully pulled from each soil core and counted.

Each year LER, LAR, and tiller density rates were assigned to three growing periods, each period to represent a season. Period 1 included the months of April and May (spring), period 2 the months of June July, and August (summer), and period 3 the months of September and October (late summer/early fall). Herbage accumulation was also assigned to growing periods. In 1999, the growing periods were the same as for LER, LAR and tiller density. However, in 2000, the third growing period was mid August and September (Table 1).

The general linear model procedure of the Statistical Analysis System (20) was used for statistical analyses. Treatments and measurements were compared using data from the $1.06 \mathrm{~m}^{2}$ center strip. Nitrogen and cutting height treatments were compared using orthogonal comparisons. The experiment was analyzed as a split plot in time with four replications. 


\section{Results}

\section{Weather}

Air temperature data were taken from the Morgantown Municipal Airport located approximately $1 \mathrm{~km}$ from the West Virginia University Livestock Farm in Morgantown, WV. Maximum and minimum daily temperatures were averaged into monthly temperatures for 1999 and 2000 (Figure 1). The temperatures for 1999 and 2000 follow the normal pattern from March to June. July was cooler in 2000 at $21.2^{\circ} \mathrm{C}$ than the normal at $22.9^{\circ} \mathrm{C}$ and 1999 was higher than the normal at $24.8^{\circ} \mathrm{C}$.

Rainfall was measured daily at the West Virginia University Agronomy Farm in Morgantown, West Virginia, located approximately $3 \mathrm{~km}$ from the Livestock Farm. The Agronomy Farm in 2000 received more rainfall than in 1999 (Figure 2). The farm received $55.17 \mathrm{~cm}$ of rain from March to September in 1999, $11.81 \mathrm{~cm}$ below normal rainfall for that time period. In 2000, from March to September the Agronomy Farm received $70.60 \mathrm{~cm}, 3.62 \mathrm{~cm}$ above normal rainfall. In 1999, August had the least rainfall at $4.01 \mathrm{~cm}, 6.36 \mathrm{~cm}$ below the norm, and April had the most at $11.28 \mathrm{~cm}, 2.55 \mathrm{~cm}$ above the norm. In 2000, May had the most rainfall at $16.69 \mathrm{~cm}, 7.05 \mathrm{~cm}$ above the norm; and September had the least at $5.59 \mathrm{~cm}, 2.55 \mathrm{~cm}$ below the norm.

\section{Soil}

The levels of $\mathrm{pH}(\mathrm{P}<0.05)$ and available $\mathrm{P}(\mathrm{P}<0.001), \mathrm{Ca}(\mathrm{P}<0.001)$, and $\mathrm{Mg}$ $(\mathrm{P}<0.001)$ in the soil were different in each year, although the differences were not large (Table 2). For the amount of available $\mathrm{K}$ in the soil, interactions were found between the nitrogen treatment and year (Appendix D), and between cutting height and year (Appendix E). The analysis showed no difference between the two sampling depths for the levels of $\mathrm{pH}$ and available $\mathrm{P}, \mathrm{K}, \mathrm{Ca}$, and $\mathrm{Mg}$. Data shown are averages of depths (Table 2) (Appendix Tables F and G). 
Table 1. Growing period, harvest dates, and rainfall received between dates each cutting treatment was harvested.

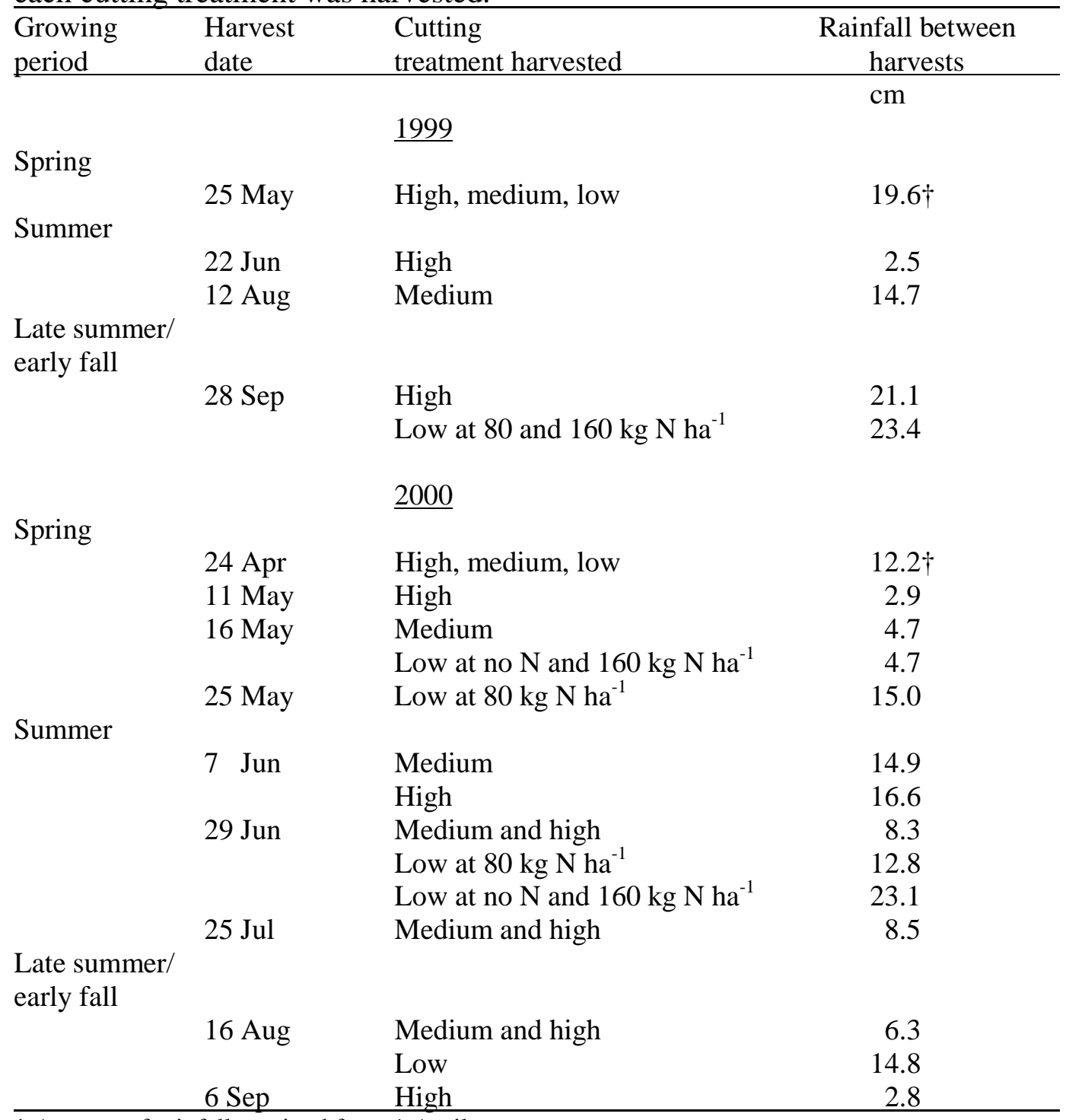

$\dagger$ Amount of rainfall received from 1 April 


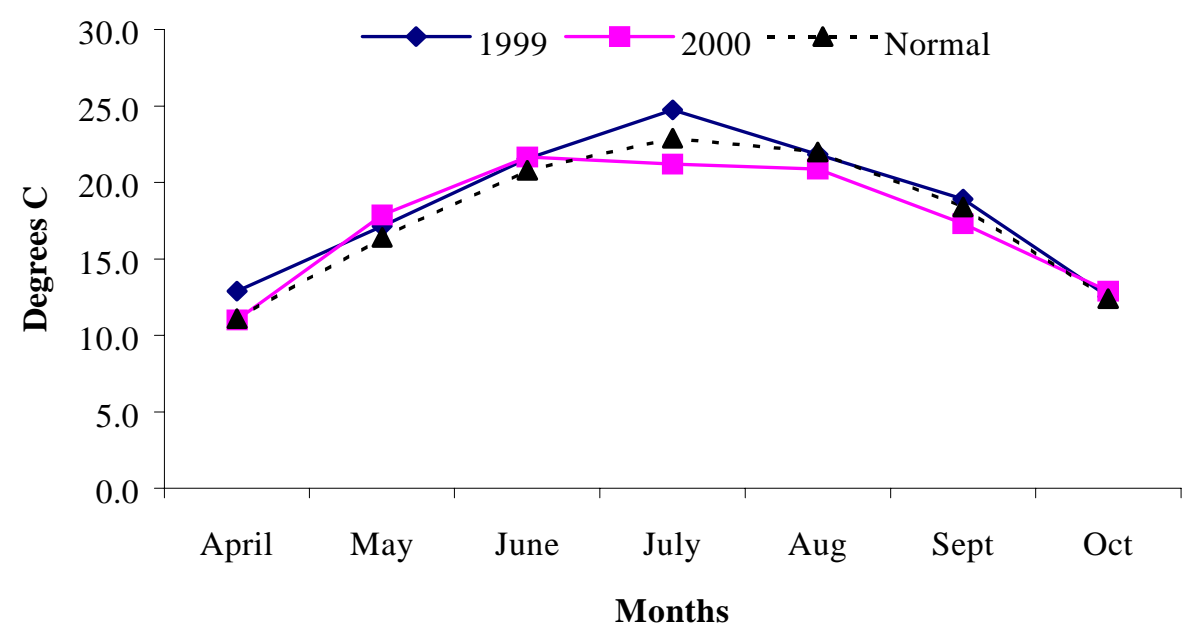

Fig. 1. Average temperatures for each month in 1999 and 2000 including normal temperatures at the Morgantown Municipal Airport. Normal temperatures were averaged from 1949 to 1993 records.

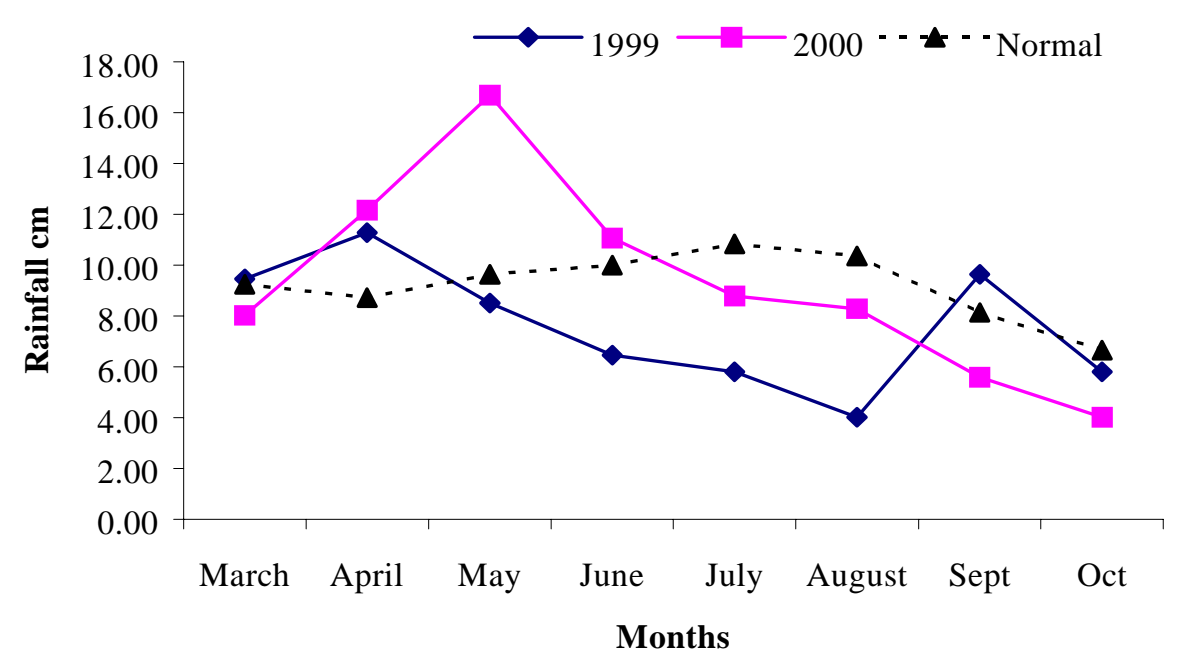

Fig. 2. Average rainfall for each month in 1999 and 2000 at the WVU Agronomy Farm. Normal rainfall from the Morgantown Municipal Airport was averaged from 1949 to 1993 records. 
Table 2. Soil analysis for each year.

\begin{tabular}{|c|c|c|c|c|c|}
\hline \multirow[b]{2}{*}{$\underline{\text { Year }}$} & \multirow[b]{2}{*}{$\mathrm{pH}$} & \multicolumn{4}{|c|}{ - available $\longrightarrow$} \\
\hline & & $\mathrm{P}$ & K & $\mathrm{Mg}$ & $\mathrm{Ca}$ \\
\hline & & & $\mathrm{kg} \mathrm{h}$ & & \\
\hline 1999 & 6.37 & 69.7 & 285 & 228 & 3999 \\
\hline 2000 & 6.29 & 62.5 & 276 & 197 & 4991 \\
\hline Significancet & $* *$ & $* * *$ & NS & $* * *$ & $* * *$ \\
\hline
\end{tabular}




\section{Herbage Accumulation}

A total of 13 harvests were made between 1999 and 2000. Table 1 shows the dates on which treatments were harvested and the amount of rainfall received between harvests. Annual herbage accumulation was affected by cutting height $(\mathrm{P}<0.001)$. More herbage was produced by the low cutting treatment than the medium and high cutting treatments (Table 3 and Appendix Table H). The effect of nitrogen application on annual herbage accumulation was not significant, however, more herbage was produced at the two treatments to which nitrogen was applied compared to the unfertilized pasture $(\mathrm{P}<$ 0.06). In 1999, drier than normal, nitrogen application produced significantly more herbage than no application (Table 4). Much more herbage accumulated in 2000 than in 1999 ( $\mathrm{P}<0.001)$. In 1999 the season was drier than 2000 and the sward produced 1961 $\mathrm{kg} \mathrm{ha}^{-1}$ of herbage, and in 2000 the sward produced $4009 \mathrm{~kg} \mathrm{ha}^{-1}$ of herbage. An interaction was found between cutting height and year (Figure 3). There was a greater difference in herbage accumulation between 1999 and 2000 at the low cutting height compared to the medium and high cutting heights. The medium and high cutting heights had similar differences in herbage accumulation between the two years.

In the 1999 growing season, harvests were made on four dates. Herbage harvested for each treatment in 1999 can be found in Table 4. Nitrogen was applied on 3 June and 10 September. The effects of cutting height and nitrogen treatment were significant $(\mathrm{P}<$ 0.001). Cutting to $2.5 \mathrm{~cm}$ and applying nitrogen resulted in the accumulation of the most herbage. There is significant evidence to show that pasture receiving no nitrogen produced less herbage than pasture to which nitrogen at 80 or $160 \mathrm{~kg} \mathrm{ha}^{-1}$ was applied, except at the $5.1 \mathrm{~cm}$ cutting height as indicated by the significant interaction between the nitrogen treatment and cutting height (Figure 4).

In the 2000 growing season, harvests were made on nine dates. Nitrogen was applied on 2 June and 30 August. The total harvested for each treatment can be seen in Table 4. Differences among cutting heights, in total herbage accumulation, were significant $(\mathrm{P}<0.001)$. The $2.5 \mathrm{~cm}$ height accumulated more herbage than the 5.1 and 7.6 $\mathrm{cm}$ heights with a yearly production of $5023 \mathrm{~kg} \mathrm{ha}^{-1}(\mathrm{P}<0.001)$. 
Table 3. Effect of cutting height, nitrogen treatment and year on annual herbage accumulation.

\section{Herbage}

accumulation

Cutting height

Low (L)

Medium (M)

$\mathrm{kg} \mathrm{ha}^{-1} \mathrm{yr}^{-1}$

High $(\mathrm{H})$

3740

2560

2655

Significance $\dagger$

L vs. $\mathrm{M}$ and $\mathrm{H}$

***

$\mathrm{M}$ vs. $\mathrm{H}$

$* * *$

NS

Nitrogen treatment

No N 2765

$80 \mathrm{~kg} \mathrm{ha}^{-1}$

$160 \mathrm{~kg} \mathrm{ha}^{-1} \quad 3069$

Significance

NS

No N vs. 80 and $160 \mathrm{~kg} \mathrm{ha}^{-1}$ NS

80 vs. $160 \mathrm{~kg} \mathrm{ha}^{-1} \quad$ NS

Year

$1999 \quad 1962$

$2000 \quad 4009$

Significance

****

$\dagger$ Significance of F test. NS, nonsignificant; *, **, ***, significant at the $0.05,0.01,0.001$ probability levels, respectively. 
Table 4. Annual herbage accumulation and per harvest for cutting, nitrogen treatments, and year.

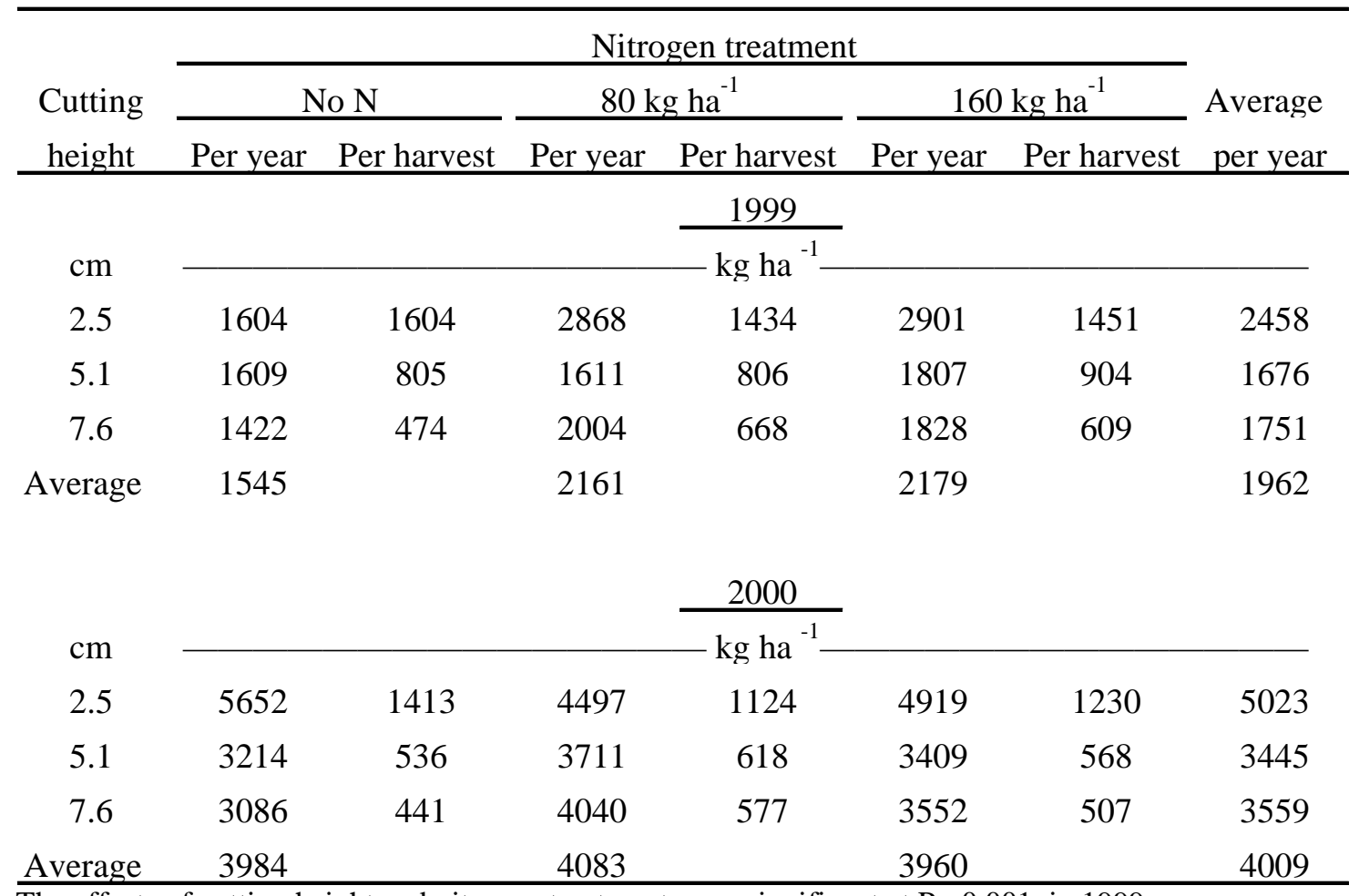

The effects of cutting height and nitrogen treatment were significant at $\mathrm{P}<0.001$, in 1999.

The effect of cutting height was significant at $\mathrm{P}<0.001$, in 2000.

The effect of year was significant at $\mathrm{P}<0.001$. 


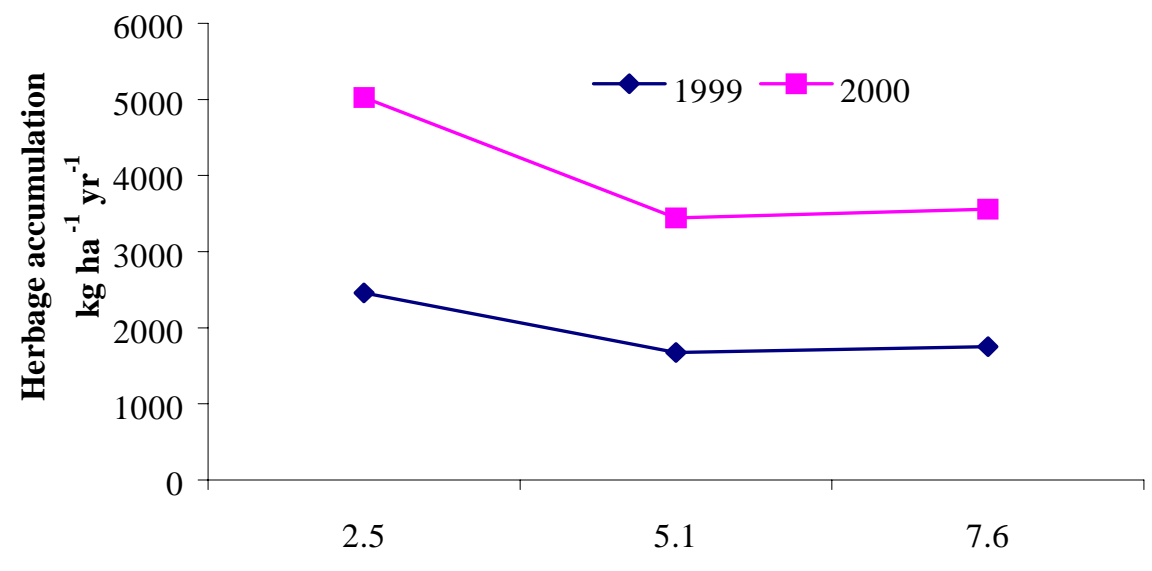

Cutting height $\mathrm{cm}$

Fig. 3. Total herbage collected at each cutting height for 1999 and 2000. The interaction between cutting height and year was significant at $\mathrm{P}<0.05$. The effects of cutting height and year were significant at $\mathrm{P}<0.001$.

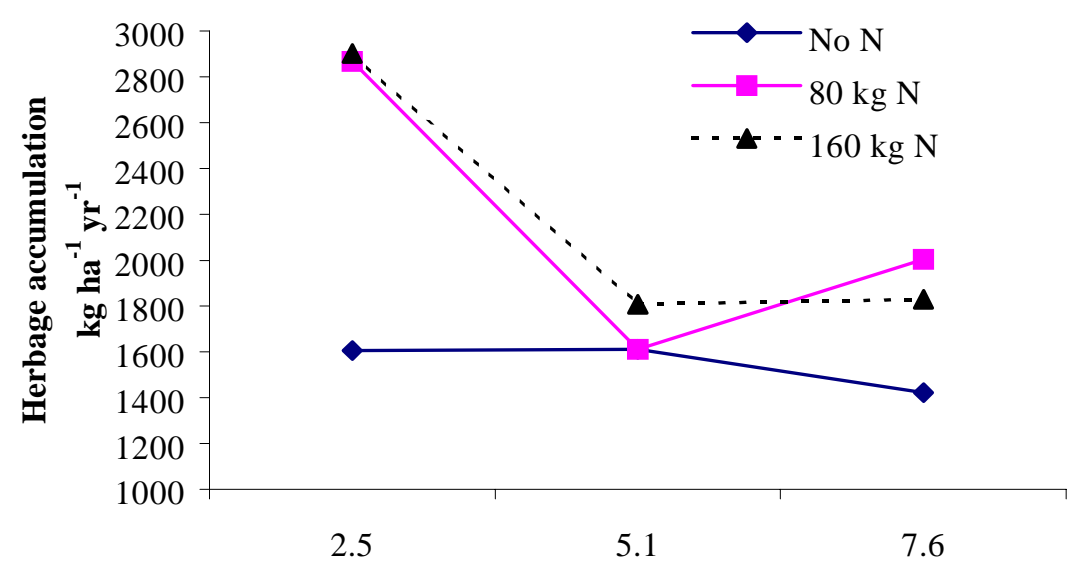

Cutting height cm

Fig. 4. Total herbage collected in 1999 at each cutting height and nitrogen treatment. The interaction between nitrogen treatment and cutting height was significant at $\mathrm{P}<0.01$. The effects of cutting height and nitrogen treatment were significant at $\mathrm{P}<0.001$. 
The effect of growing period on herbage accumulation in 2000 was significant ( $\mathrm{P}$ $<0.001$ ) (Appendix Tables I and J). Spring had the highest herbage accumulation at 1648 $\mathrm{kg} \mathrm{ha}^{-1}$, summer and late summer/early fall accumulation were less at 1471 and $890 \mathrm{~kg}$ $\mathrm{ha}^{-1}$, respectively. Clipping to a low height produced the most herbage $(\mathrm{P}<0.001)$, however, this was not found during the summer as seen in the interaction between cutting height and growing period (Figure 5). Clipping to 5.1 or $7.6 \mathrm{~cm}$ had lower herbage accumulation than clipping to $2.5 \mathrm{~cm}$ during spring and late summer/early fall. The effect of nitrogen treatment on herbage accumulation was not significant.

\section{Botanical composition}

Both estimates of botanical composition gave similar results (Appendix Tables K, L, M, and N). The estimates using dry weights will be used. For the 1999 growing season, the proportions of legume $(\mathrm{P}<0.01)$ and grass $(\mathrm{P}<0.05)$ in the sward were different among the three cutting heights (Figure 6). Cutting to a height of $7.6 \mathrm{~cm}$ resulted in more legumes than to 2.5 or $5.1 \mathrm{~cm}$ heights. The $2.5 \mathrm{~cm}$ height contained more legumes than the $5.1 \mathrm{~cm}$ height. Cutting to $5.1 \mathrm{~cm}$ resulted in the most grass. Weeds and senesced material percentages remained below $10 \%$ for all cutting heights. Botanical composition for 2000 showed no differences in the proportions of legume, grass, weed, or senesced material over the cutting or nitrogen treatments.

The two years were different for the proportions of grass $(\mathrm{P}<0.01)$, legume, weed, and senesced material $(\mathrm{P}<0.05)$ in the herbage mass (Figure 7, Appendix Table K). In 1999, the sward contained more grass and senesced material and less legume and weeds than in 2000. The proportions of grass $(\mathrm{P}<0.001)$, legume $(\mathrm{P}<0.01)$ and senesced $(\mathrm{P}<0.001)$ material were different among the growing periods (Figure 8). Percentage of legumes increased in summer and grass percentage decreased compared to spring or late summer/early fall. The amount of senesced material increased from spring to late summer/early fall. Weeds remained around $10 \%$ over the whole season for the years combined. 


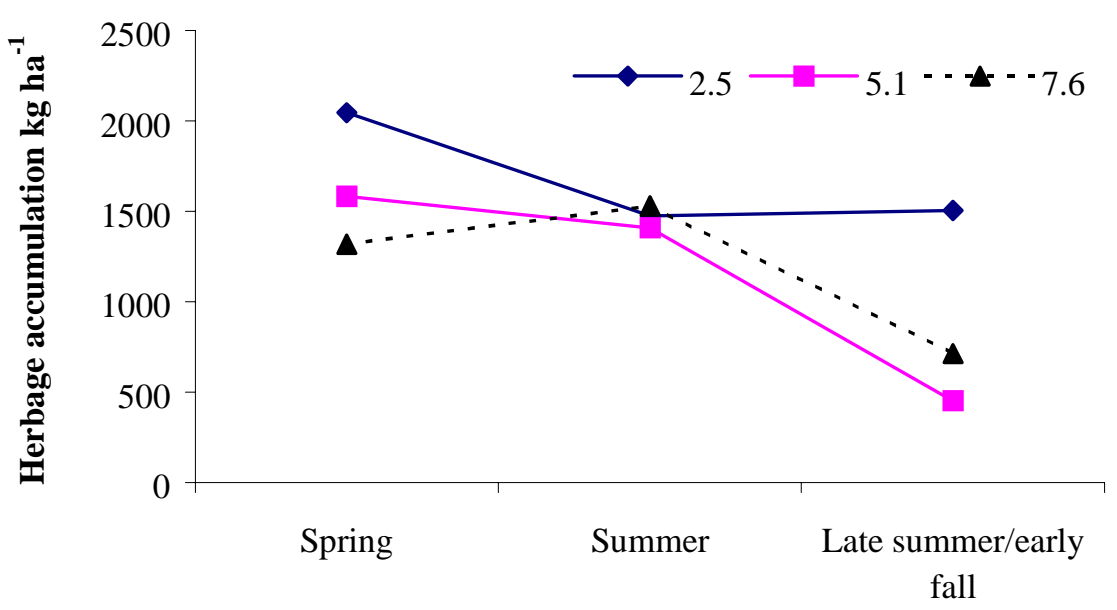

Growing period

Fig. 5. Total herbage collected at each cutting height and growing period in 2000. The interaction between cutting height and growing period was significant at $\mathrm{P}<0.0001$. The effects of cutting height and growing period were significant at $\mathrm{P}<0.001$.

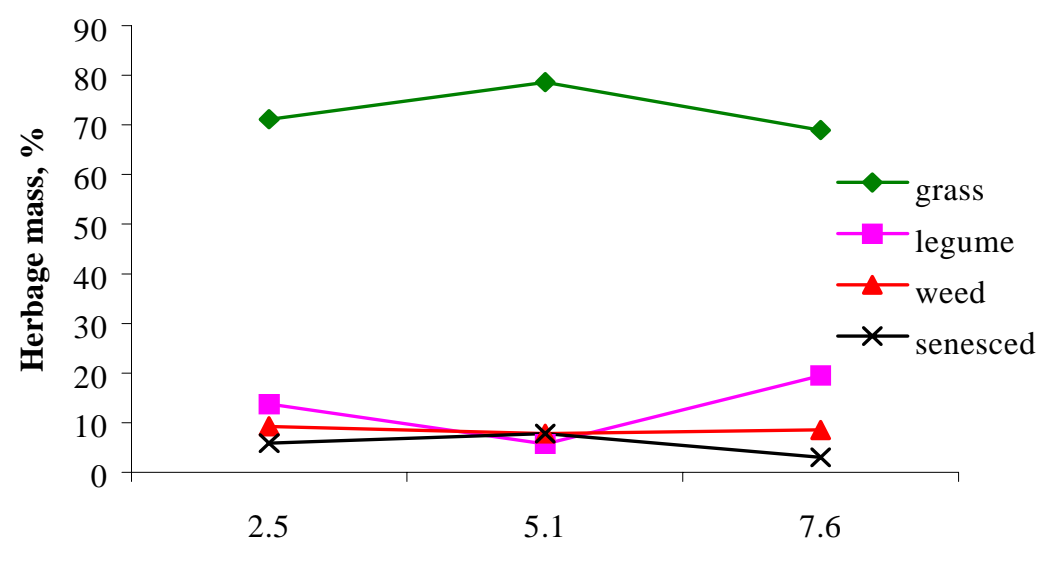

Cutting height $\mathrm{cm}$

Fig. 6. Botanical composition at each cutting height in 1999. The effect of cutting height was significant for grass at $\mathrm{P}<0.05$; legume at $\mathrm{P}<0.01$; weed and senesced, NS. 


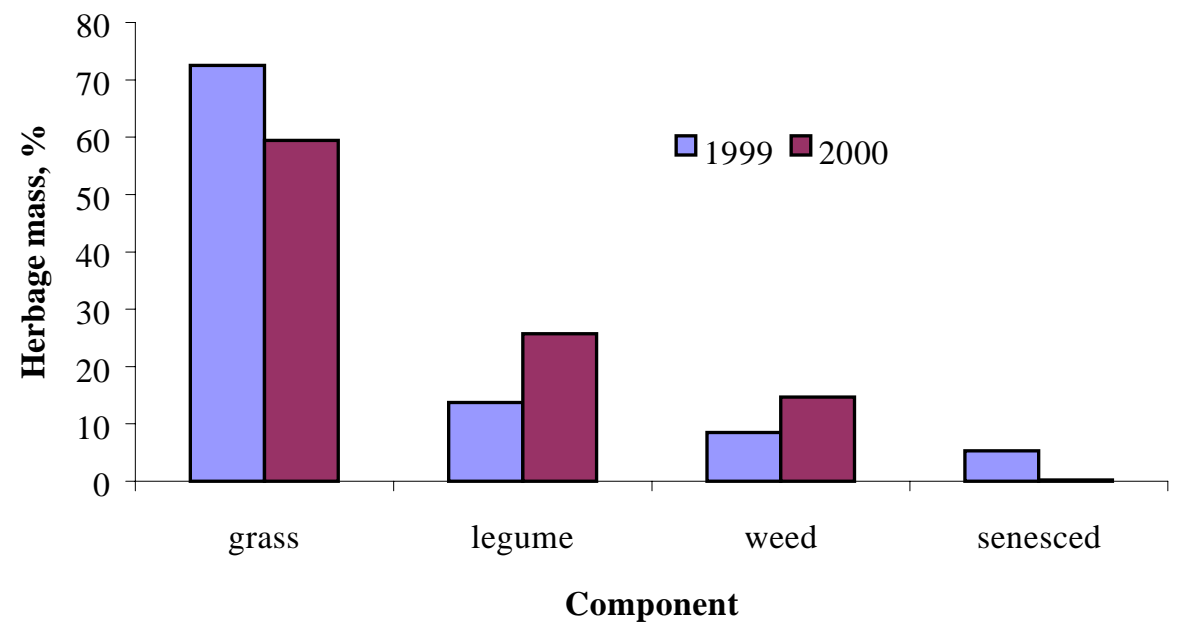

Fig. 7. Botanical composition for 1999 and 2000. The effect of year was significant for grass at $\mathrm{P}<0.01$; legume, weed and senesced material at $\mathrm{P}<0.05$.

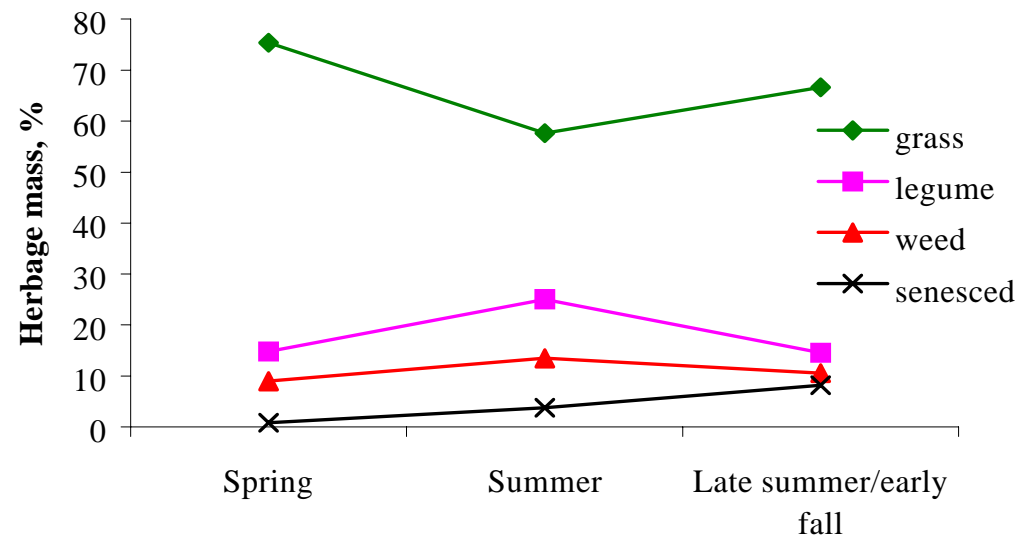

Growing period

Fig. 8. Botanical composition for each growing period (average for 1999 and 2000). Effect of growing period was significant for grass and senesced material at $\mathrm{P}<0.001$; legume at $\mathrm{P}<0.01$; senesced, NS. 
The percentage of clover was visually estimated in June of 2000. The three cutting heights were found to have different proportions of clover (Appendix Tables $\mathrm{O}$ and $\mathrm{P}$ ). The $2.5 \mathrm{~cm}$ cutting height had the highest percentage of clover at $31 \%$ and was significantly different from the 5.1 and $7.6 \mathrm{~cm}$ cutting heights with 19 and $23 \%$ clover coverage, respectively $(\mathrm{P}<0.05)$. The medium cutting height had the least clover content at the 80 and $160 \mathrm{~kg} \mathrm{~N} \mathrm{ha}^{-1}$ treatments that can be seen by the interaction between nitrogen and cutting height treatments (Figure 9). Plots to which no nitrogen was applied had significantly more clover $(\mathrm{P}<0.05)$ than plots supplied with nitrogen but not at the high cutting height where all nitrogen treatments were similar. Clover content was highest at the $2.5 \mathrm{~cm}$ cutting height when nitrogen was added at $160 \mathrm{~kg} \mathrm{ha}^{-1}$.

\section{Leaf Extension Rate}

Leaf extension rates were different for each year $(\mathrm{P}<0.001)$ (Appendix Tables $\mathrm{O}$ and Q). The average LER in 1999 was $0.30 \mathrm{~cm} \mathrm{~d}^{-1}$ and $0.41 \mathrm{~cm} \mathrm{~d}^{-1}$ in 2000 (Figure 10). However, in 1999, early spring and late summer/early fall showed the highest LER with summer being the slowest. In 2000, LER increased slightly from spring to summer and then decreased in late summer/early fall.

In 1999, spring and late summer/early fall had higher leaf extension rates than summer at the 0 and $80 \mathrm{~kg} \mathrm{~N}^{-1}$ rates. However, leaf extension rate increased throughout the season at the $160 \mathrm{~kg} \mathrm{~N} \mathrm{ha}^{-1}$ treatment as seen in the interaction between nitrogen treatment and growing period (Figure 11). In 1999, LER was lowest at the 2.5 $\mathrm{cm}$ cutting height for spring and summer as seen by the interaction between cutting height and growing period (Figure 12). The $7.6 \mathrm{~cm}$ cutting height had the highest LER in summer and late summer/early fall. Differing from 1999, in 2000 there was little difference in LER between the low and medium cutting heights (Figure 13). However, the $7.6 \mathrm{~cm}$ cutting height had the highest LER in the summer, and all cutting heights were similar in the spring and late summer/early fall.

During 1999, significant evidence was found to show a difference among the three nitrogen treatments $(\mathrm{P}<0.001)$, but there was an interaction between nitrogen treatment and cutting height (Figure 14). Plots receiving no nitrogen had a LER of 


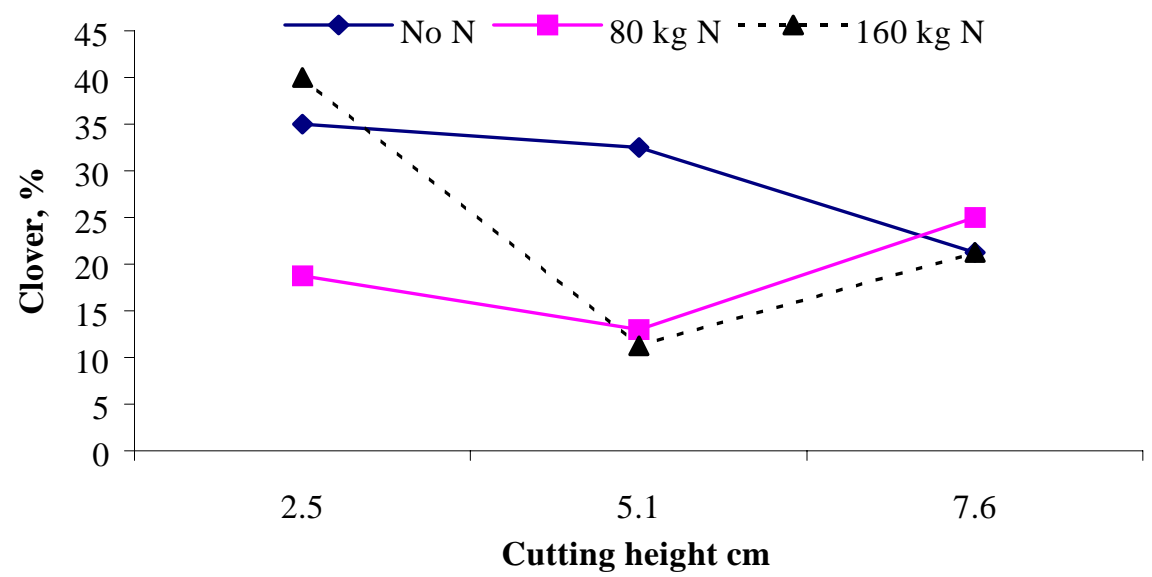

Fig. 9. Visual estimate of the percentage of clover at each cutting height and nitrogen treatment in 2000. The interaction between cutting height and nitrogen treatment was significant at $\mathrm{P}<0.05$. The effect of cutting height was significant at $\mathrm{P}<0.05$.

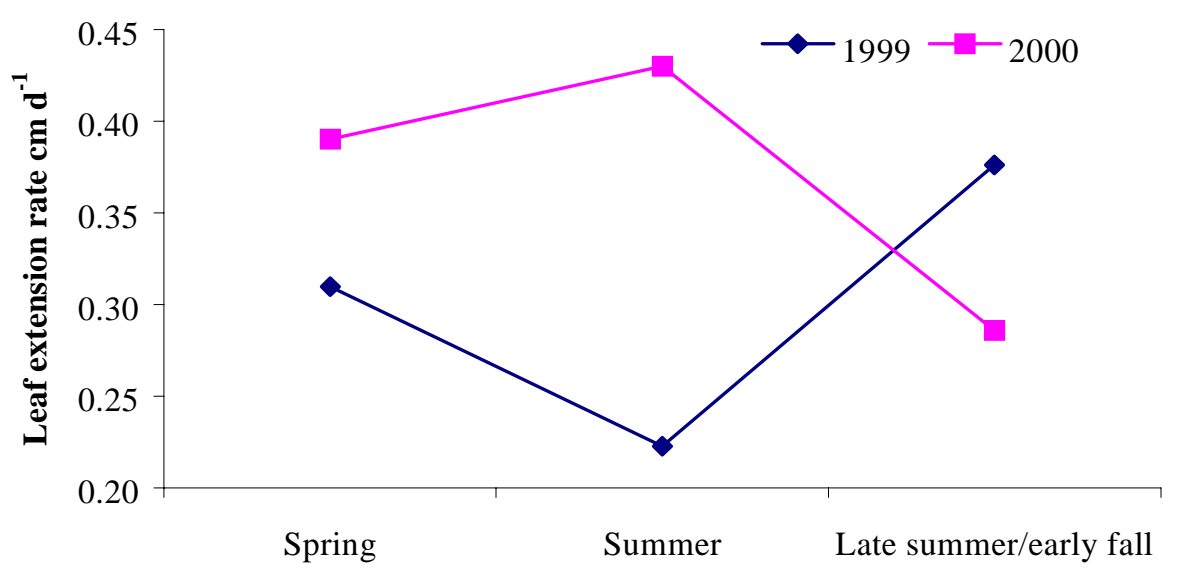

Growing period

Fig. 10. Leaf extension rate for each growing period in 1999 and 2000.

The effect of growing period was significant at $\mathrm{P}<0.001$. The effect of year was significant at $\mathrm{P}<0.001$. 


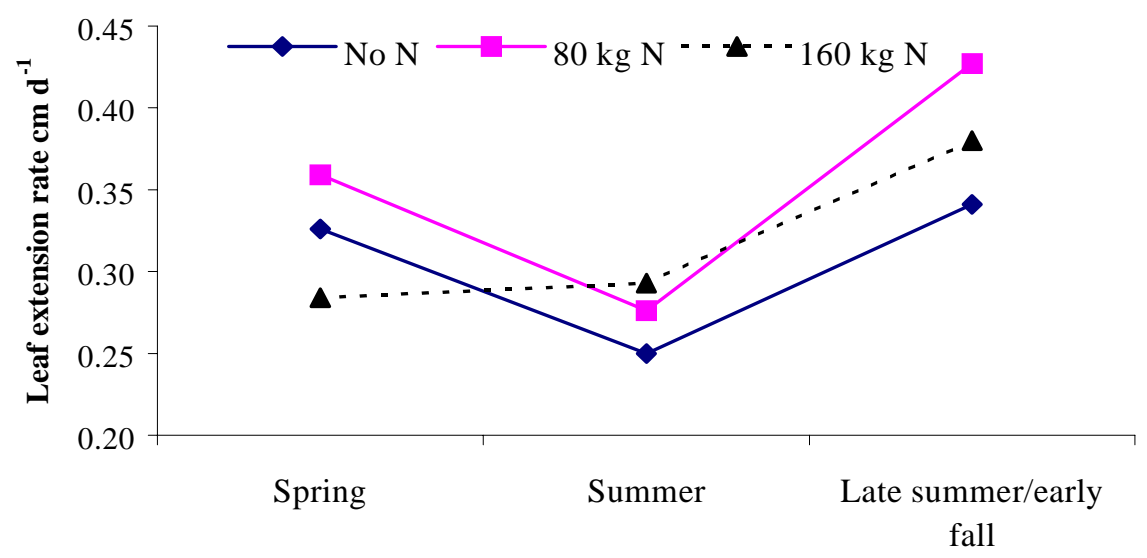

Growing period

Fig. 11. Leaf extension rate for growing period at each nitrogen treatment in 1999. The interaction between growing period and nitrogen treatment was significant at $\mathrm{P}<0.001$. The effects of nitrogen and cutting treatments were significant at $\mathrm{P}<0.01$. The effect of growing period was significant at $\mathrm{P}<0.001$.

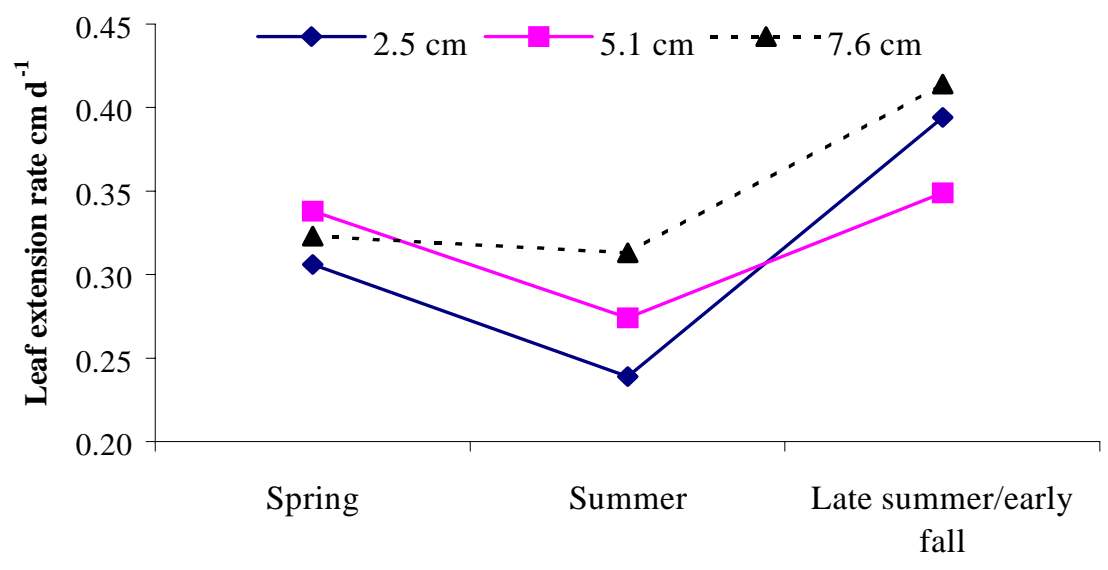

Growing period

Fig. 12. Leaf extension rate in 1999 at each growing period and cutting height. The interaction between cutting height and growing period was significant at $\mathrm{P}<0.01$. The effect of cutting height was significant at $\mathrm{P}<0.01$. The effect of growing period was significant at $\mathrm{P}<0.001$. 


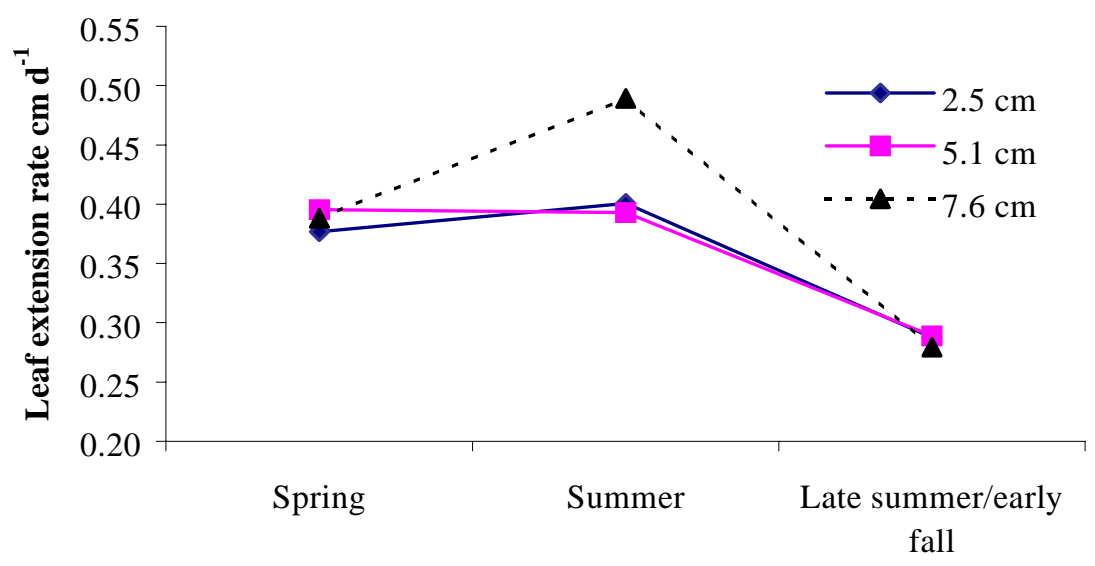

Growing period

Fig. 13. Leaf extension rate in 2000 at each growing period and cutting height. The interaction between cutting height and growing period was significant at $\mathrm{P}<0.05$. The effect of cutting height was significant at $\mathrm{P}<0.01$. The effect of growing period was significant at $\mathrm{P}<0.001$.

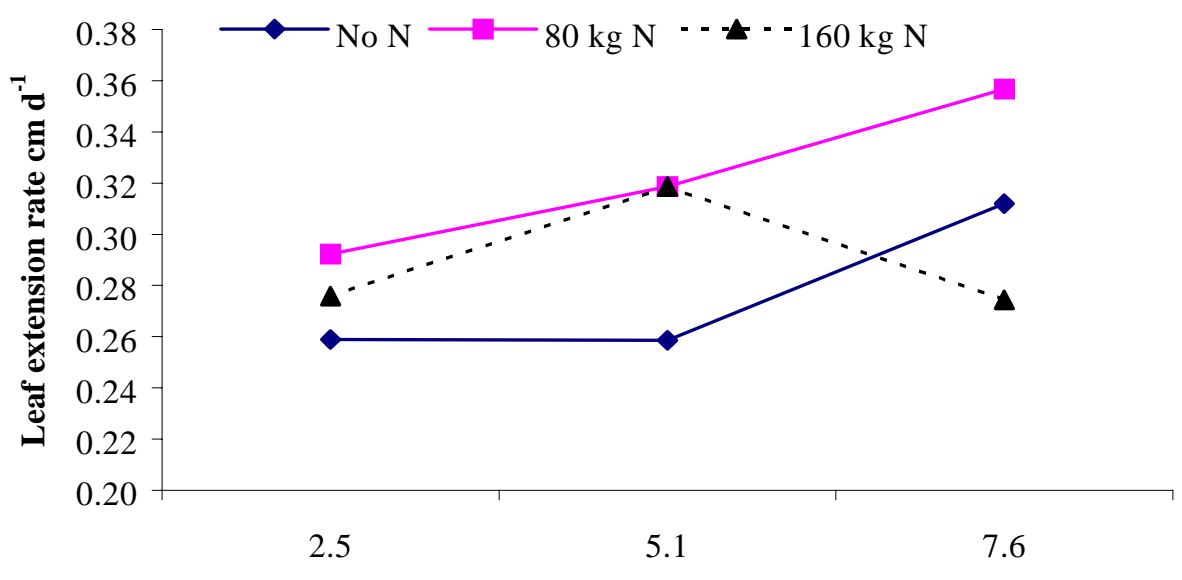

Cutting height cm

Fig. 14. Leaf extension rate for cutting height and nitrogen treatment in 1999. The interaction between cutting height and nitrogen treatment was significant at $\mathrm{P}<0.01$. The effects of cutting height and nitrogen treatment were significant at $\mathrm{P}<0.01$. 
$0.27 \mathrm{~cm} \mathrm{~d}^{-1}$, the $80 \mathrm{~kg} \mathrm{~N} \mathrm{ha}^{-1}$ plots $0.32 \mathrm{~cm} \mathrm{~d}^{-1}$, and the $160 \mathrm{~kg} \mathrm{~N} \mathrm{ha}^{-1}$ plots $0.29 \mathrm{~cm} \mathrm{~d}^{-1}$. However, Figure 14 illustrates that at the high cutting height LER of the sward that received $160 \mathrm{~kg} \mathrm{~N} \mathrm{ha}^{-1}$ was lower than the sward that received the other nitrogen treatments.

It was noticed that the younger leaves appeared to grow faster than the older leaves, thus, measured leaves were separated into three categories according to their length. Category 1 represented a leaf length between 0 and $2.0 \mathrm{~cm}$, category 2 represented lengths from 2.1 and $4 \mathrm{~cm}$, and category 3 represented lengths $4.1 \mathrm{~cm}$ and longer. Over the two years, the effect of leaf category on LER was significant $(\mathrm{P}<$ $0.001)$. Category 1 leaves at $0.39 \mathrm{~cm} \mathrm{~d}^{-1}$ extended more rapidly than category 2 leaves at $0.35 \mathrm{~cm} \mathrm{~d}^{-1}$ and category 3 leaves at $0.24 \mathrm{~cm} \mathrm{~d}^{-1}(\mathrm{P}<0.01)$. Leaf extension rate for category 2 leaves was higher than for category 3 leaves $(\mathrm{P}<0.01)$. The younger the leaf's age, the faster it extended. As the season progressed LER for the youngest leaves increased as seen by the interaction between category and growing period (Figure 15), however, the LER of category 3 leaves was slowest in summer and late summer/early fall. At the beginning of the experiment, spring, there was little difference in LER among the categories and as the growing season progressed, the difference became greater. Figure 15 illustrates that category 1 and 2 had a higher LER than category 3 in summer and late summer/early fall $(\mathrm{P}<0.001)$. After the second nitrogen application LER of leaves in categories 1 and 2 increased more than those in category 3. Leaf extension rate of category 3 leaves remained low after both nitrogen applications.

\section{Leaf Appearance Rate}

Leaf appearance rate (LAR) was derived from leaf extension records. It was calculated as the number of new leaves appearing per day. For the two years combined, the effect of growing period was significant ( $\mathrm{P}<0.001)$ (Appendix Tables $\mathrm{O}$ and $\mathrm{R}$ ). Spring had a rate of 0.052 , summer had a rate of 0.048 , and late summer/early fall had a rate of 0.067 new leaves appearing per day. In 1999, LAR decreased from spring to summer when conditions became dry and then increased from summer to late summer/early fall when conditions were not as dry (Figure 16). In 2000, the LAR 


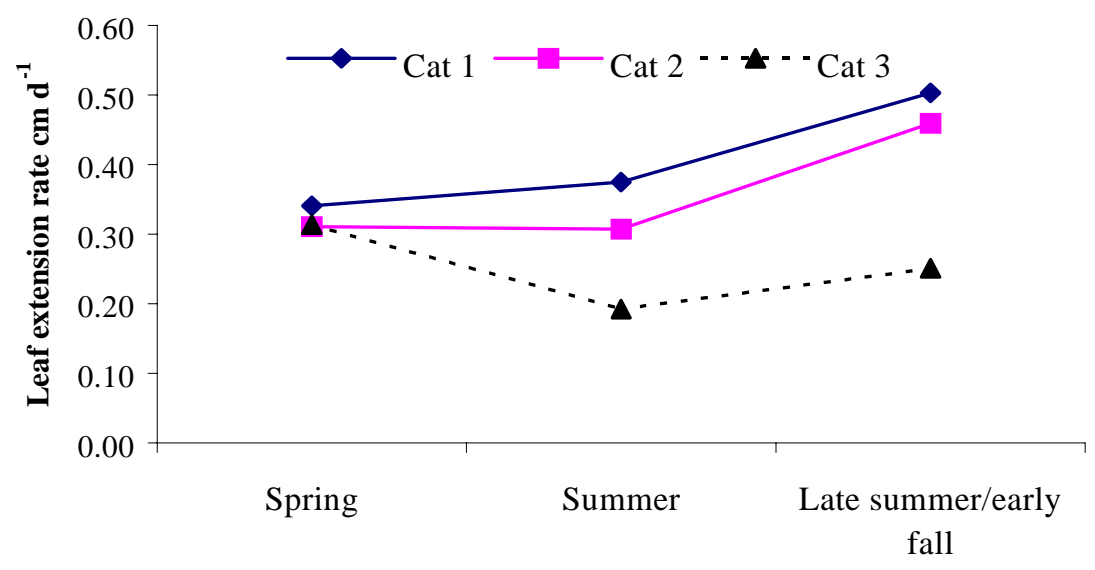

Growing period

Fig. 15. Leaf extension rate for growing period and leaf category. The interaction between category and growing period was significant at $\mathrm{P}<0.001$. The effects of category and growing period were significant at $\mathrm{P}<0.001$. Category 1 represented leaf lengths 0 to $2.1 \mathrm{~cm}$, category 2 2.1 to $4 \mathrm{~cm}$, and category $34.1 \mathrm{~cm}$ and longer.

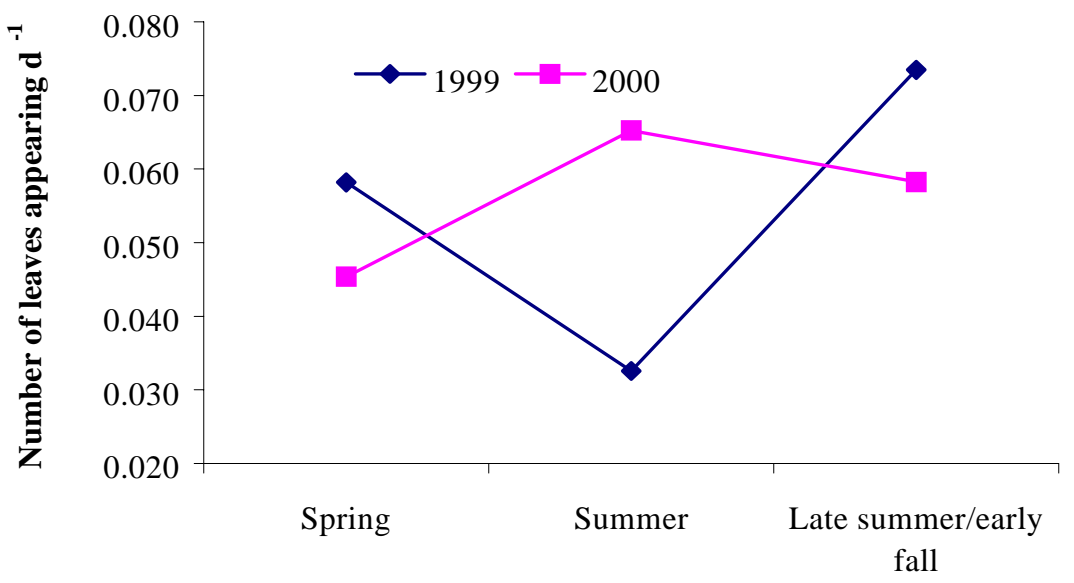

Growing period

Fig. 16. Leaf appearance rate for each year and growing period. The effect of growing period was significant in each year at $\mathrm{P}<0.001$. The effect of year was not significant. 
increased from spring to summer, and then decreased slightly from summer to late summer/early fall.

The LAR was different among the three cutting heights $(\mathrm{P}<0.001)$. The LAR of the sward cut at the low cutting height was 0.060; at the medium 0.051, and at the high cutting height was 0.056 new leaves appearing per day. The LAR of the plots cut to 2.5 $\mathrm{cm}$ was higher than that of plots cut to 5.1 or $7.6 \mathrm{~cm}(\mathrm{P}<0.05)$. However, the interaction presented in Figure 17 shows that LAR in 1999 remained almost the same for all three cutting heights. In 2000, the LAR was highest at the $2.5 \mathrm{~cm}$ cutting height and lowest at the $5.1 \mathrm{~cm}$ cutting height.

A significant interaction was found between cutting height and growing period for the 2000 growing season (Figure 18). There was no difference among the cutting heights in the spring. The LAR at the low cutting height increased as the season progressed, however, the LAR in the plots at medium and high cutting heights decreased from summer to late summer/early fall.

\section{Tiller Density}

The number of tillers $\mathrm{m}^{-2}$ was calculated from a $26.4 \mathrm{~cm}^{2}$ area core of turf. In 1999, number of live and dead shoots was recorded. In 2000, the number of live shoots was recorded. In 1999, the number of tillers increased at each sampling date from spring through fall $(\mathrm{P}<0.01)$. In the spring of 1999, there were 2851 tillers, in summer 4081 tillers, and in late summer/early fall 4514 tillers $\mathrm{m}^{-2}$.

There were many more tillers in 2000 than in 1999 ( $\mathrm{P}<0.001)$ (Appendix Tables $\mathrm{O}$ and R). In 1999, tiller numbers averaged $3833 \mathrm{~m}^{-2}$ and in 2000 there was 10,546 tillers $\mathrm{m}^{-2}$. Growing period was found to influence tiller density $(\mathrm{P}<0.05)$. Late summer/early fall had the most at 8335 tillers $\mathrm{m}^{-2}$, spring had 7103 tillers $\mathrm{m}^{-2}$, and summer had the least with 6648 tillers $\mathrm{m}^{-2}$. There was a difference in tiller numbers among the three nitrogen treatments $(\mathrm{P}<0.05)$. Plots receiving no nitrogen had the least at 6418 tillers $\mathrm{m}^{-2}(\mathrm{P}<$ 0.01 ). The 80 and $160 \mathrm{~kg} \mathrm{~N} \mathrm{ha}^{-1}$ rate plots did not differ in tiller density with 8031 and 7596 tillers $\mathrm{m}^{2}$, respectively. 


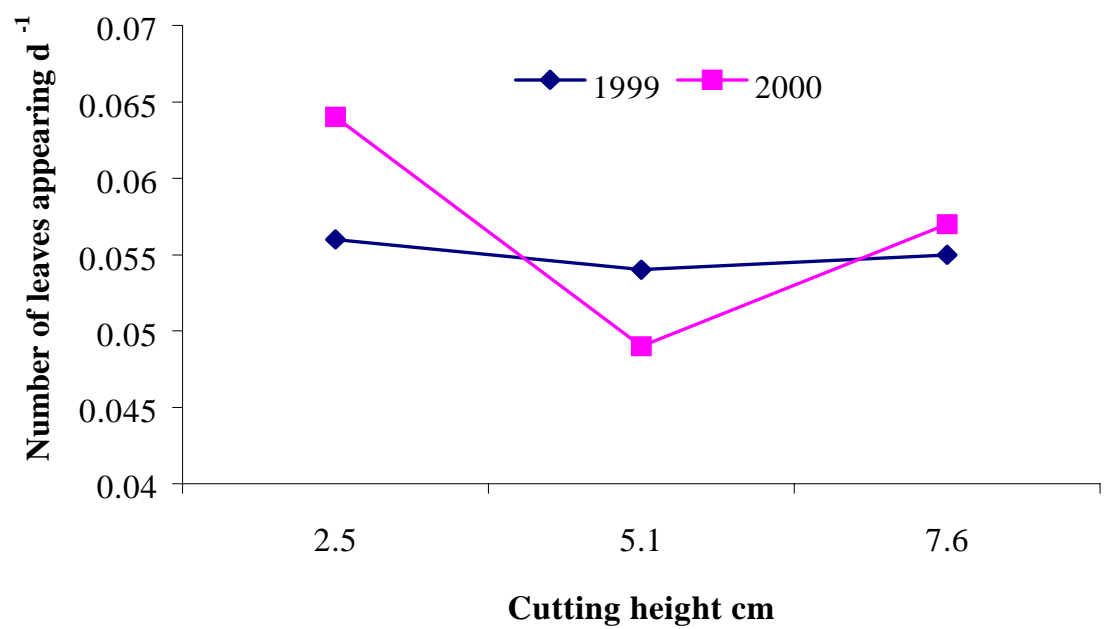

Fig. 17. Leaf appearance rate for year and cutting height. The interaction between year and cutting height was significant at $\mathrm{P}<0.05$. The effect of cutting height was significant at $\mathrm{P}<0.01$. The effect of year was not significant.

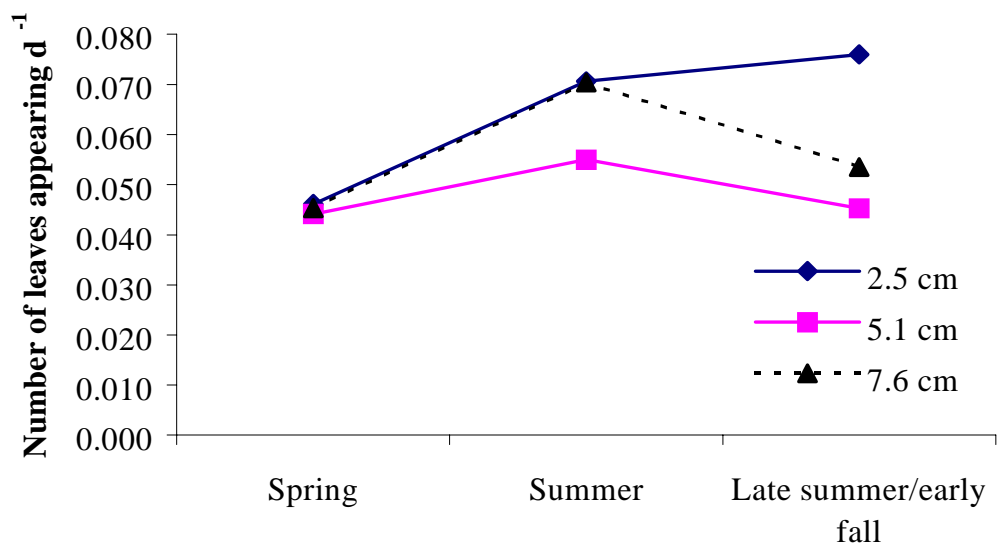

Growing period

Fig. 18. Leaf appearance rate for growing period and cutting height in 2000. The interaction between growing period and cutting height was significant at $\mathrm{P}<0.05$. The effects of cutting height and growing period were significant at $\mathrm{P}<0.001$. 


\section{Discussion}

\section{Effect of year and season}

Differences in rainfall and air temperatures during the growing season contributed to differences in the results between the two years. The growing season of 2000 received more rainfall, with cooler temperatures in July and August (Figures 1 and 2). Herbage accumulation was approximately double in 2000 compared to 1999. The sward in 2000 contained more legumes and weeds with less grass and senesced material than in 1999. These results are similar to those of Appadurai and Holmes (2) who found that clover content is greater when conditions are wet than dry.

Harvests were grouped by growing periods (Table 1). The effect of growing period on all cutting height and nitrogen treatments was analyzed in 2000. Less herbage was produced as the season progressed (Appendix Table I). The interaction between cutting height and growing period showed that herbage accumulation at the low cutting height decreased less as the season progressed compared to the medium and high cutting managements (Figure 5).

Rainfall was closer to normal in the summer of 2000 and more harvests were made than in the other growing periods. However, herbage accumulation in the summer was less than that in spring but more than that in late summer/early fall. There was no effect of cutting height on herbage accumulation during the summer (Figure 5). Herbage in plots cut at 5.1 and $7.6 \mathrm{~cm}$ was clipped more frequently so that the total herbage accumulation in the summer neared that of plots harvested at the low heights, which were clipped only once. During the summer, legumes and weeds thrived best (Figure 8). Legumes have a higher optimum temperature for growth than Kentucky bluegrass (19), which had the lowest percentage in the sward during the summer. Leaf extension rate and leaf appearance rate were slowest during this growing period in 1999 and fastest in 2000 (Figures 10 and 16). Tiller density during the summer was also the lowest compared to the other growing periods. An indication of a "summer slump" can be seen in the herbage accumulation data for 1999. In contrast to spring and late summer/early fall of 1999, the summer rainfall was much less than normal. When rainfall is higher, as in the summer of 2000 , growth rates are higher than when conditions are dry $(2,6)$. 
Least herbage was collected in late summer/early fall. From summer to late summer/early fall, the proportion of grass in the sward increased slightly and legumes decreased (Figure 8), which is similar to the findings of Robinson and Sprague who noted that clover optimal growth temperatures were higher than those for Kentucky bluegrass (19). Overall, LER and LAR were most rapid in late summer/early fall (Appendix Table O). Tiller density increased sharply from summer to late summer/early fall as temperatures became cooler which is similar to the studies of Harrison (14) and Madison (15).

In the spring months all three categories of leaf length had similar leaf extension rates (Figure 15). In summer and late summer/early fall the oldest (category 3) leaves extended the slowest while the youngest (category 1) leaves extended fastest. There was a greater difference between category 3 and 1 or 2 than between category 1 and 2 during summer and summer/early fall. The younger a leaf's age the more quickly it extended as the growing season progressed. Older leaves did not increase in length as quickly as the younger leaves.

\section{Effects of cutting height}

Herbage accumulation

The results from the experiment show that more herbage accumulated when the sward was cut to $2.5 \mathrm{~cm}$ than to 5.1 or $7.6 \mathrm{~cm}$ (Table 3). In 1999, cutting to $2.5 \mathrm{~cm}$ and applying nitrogen produced most herbage (Table 4). In 2000, however, nitrogen application did not affect herbage accumulation, probably because plots not receiving nitrogen contained more legumes than those fertilized with nitrogen (Appendix Table $\mathrm{O}$ ). Legumes may have contributed nitrogen, thus increasing herbage accumulation. With $31 \%$ clover, the plots cut to $2.5 \mathrm{~cm}$ with no nitrogen application had more herbage accumulation than those supplied with nitrogen, with 20 and 13\% clover at 80 and $160 \mathrm{~kg}$ $\mathrm{N} \mathrm{a}^{-1}$, respectively.

Botanical composition

Among the three cutting heights, plots harvested at $5.1 \mathrm{~cm}$ contained the most grass and least legumes (Figure 6). The visual estimate of clover in 2000 (Appendix 
Table O) showed similar results and agree with the findings of Robinson and Sprague (19) who found that cutting to no less than $5 \mathrm{~cm}$ resulted in a dense sod of Kentucky bluegrass. The high cut plots contained most legumes according to the dry weights and the low cut plots had the most legumes according to the visual estimate. Possibly, the low cutting height treatment may have favored a stand of white clover, which tolerates low clippings, and the high cutting height may have favored red clover, which tolerates higher clipping heights.

\section{Leaf extension rate}

The LER among the three cutting heights followed a similar pattern over the three growing periods with rates decreasing from spring to summer and increasing from summer to late summer/early fall in 1999 (Figure 12). There was a greater difference in LER among the three cutting heights in the summer than in the spring. In the summer, the lower the cutting height the slower the leaves extended. Perhaps the lower cutting height allowed a higher evaporation of soil moisture due to a lower canopy cover, whereas, the high cutting height, with more of a canopy after cutting, retained more soil moisture and plant growth rate increased. However, in 2000, LER among the cutting heights were similar in each growing period except for summer when the high cutting height had the highest LER (Figure 13). These similar rates may be attributed to closer to normal soil moisture levels in 2000 compared to 1999. Baker and Younger (4) found that adequate soil moisture in well drained soils increased LER.

\section{Leaf appearance rate}

Only in 2000 were the leaf appearance rates among the cutting heights different (Appendix Tables $\mathrm{O}$ and $\mathrm{R}$ ). Leaf appearance may have been more frequent in the low cut plots because more of the top growth was removed stimulating the plant to produce more new leaves, whereas, at the higher cutting height more young short leaves would have remained after harvest and continued to grow, reducing the need to produce new leaves. 


\section{Effects of nitrogen}

In 1999, when the percentage of legume was less that in 2000 (Figure 7), applying nitrogen increased herbage accumulation (Table 4), although, there was no difference between the two rates of applied nitrogen. For the plots supplied with the high rate of nitrogen LER increased as the growing season progressed with the greatest increase in rate being from summer to late summer/early fall (Figure 11). The LER of the plots receiving no nitrogen and $80 \mathrm{~kg} \mathrm{~N} \mathrm{ha}^{-1}$ decreased from spring to summer and then increased into late summer/early fall. Leaf extension rate was fastest in the plots supplied with $80 \mathrm{~kg} \mathrm{~N} \mathrm{ha}^{-1}$ during the spring and late summer/early fall. Temperature may also affect growth rates in the spring and late summer/early fall. More above ground growth is produced in the early spring and late summer when temperatures are cooler and root and rhizome growth is produced during the summer when temperatures are warmer (15). Warm temperatures allow nutrients to become available in the soil for plant uptake, which encourages rhizome growth. As temperatures increase transpiration increases. If soil moisture is limited this increase in temperature causes respiration and the concentration of intercellular carbon dioxide within the plant to increase. Stomates close and if the temperature rises above 30 to $35^{\circ} \mathrm{C}$, the efficiency of photosynthesis and nutrient uptake decreases.

More tillers were found when nitrogen was applied compared to no nitrogen application (Appendix Table O). The greatest effect of nitrogen was found after the late summer application when tiller numbers were highest in all treatments.

\section{Conclusion}

The results of this experiment agree with the studies in the literature showing that the growth of Kentucky bluegrass is greatest under cool and moist conditions in spring and late summer/early fall. When weather is hot rate of top growth declines, and if moisture is available, clover can out-compete Kentucky bluegrass $(14,15)$. By clipping to a height of $5.1 \mathrm{~cm}$, a higher proportion of grass was obtained compared to clipping to 2.5 or $7.6 \mathrm{~cm}$ when good clover stands resulted. In 2000, the wet year, more legume and weeds accumulated with less grass and senesced material. 
Cutting to a low level $(2.5 \mathrm{~cm})$ produced $40 \%$ more herbage compared to cutting to 5.1 or $7.6 \mathrm{~cm}$. All cutting treatments were allowed to recover to the same preharvest height. Herbage accumulation was double in 2000 compared to 1999. Nitrogen increased herbage accumulation by $40 \%$ in 1999 , but not in 2000 . If the proportion of clover is above $30 \%$ then applying nitrogen may not increase herbage production, as found in this experiment in 2000 .

Leaf extension rate was highest in young leaves during summer and late summer/early fall, with ample rainfall, cool temperatures, and when nitrogen was applied. Cutting height had little effect on LER except at the high cutting height in the summer when LER was highest. More leaves appeared in a year of normal rainfall at a low cutting height, compared to a dry year and higher cutting heights. Leaf appearance rate and LER were most rapid in late summer/early fall. Late summer nitrogen application increased tiller density in late summer/early fall.

Fall stored carbohydrate reserves are important for Kentucky bluegrass to survive winter and produce a flush of growth in the early spring. If soil available nitrogen is low then a moderate application of nitrogen in late summer may be beneficial. As temperatures increase in the summer months and soil moisture declines, the growth rate of Kentucky bluegrass declines and it competes less with clover and weeds. When weather becomes cooler in the late summer/early fall, soil moisture becomes more available and the growth rate of Kentucky bluegrass increases.

This study showed that more herbage was obtained if the sward was clipped less frequently at a low level $(2.5 \mathrm{~cm})$ compared to clipping at 5.1 and $7.6 \mathrm{~cm}$, which were clipped more frequently. Applying nitrogen may not be beneficial if the clover content of the sward is above $30 \%$. Moderate levels of nitrogen, $80 \mathrm{~kg} \mathrm{ha}^{-1}$ in split applications applied in the late summer, increased LER when temperatures were cool and soil moisture was adequate. In contrast to no nitrogen application, applying nitrogen in the late summer increased tiller density during late summer/early fall. However, applying nitrogen during late spring did not increase tiller density in summer. 


\section{References}

1. Acunap, G.H., and D. Wilman. 1993. Effects of cutting height on the productivity and composition of perennial ryegrass-white clover swards. J. Agric. Sci. 121:29-37.

2. Appadurai, R., and W. Holmes. 1964. The influence of stage of growth, closeness of defoliation, and moisture on growth and productivity of a ryegrass-white clover sward. J. Agric. Sci. 62:327-332.

3. Archer, S.G., and C.E. Bunch. 1953. A Manual of Pasture and Range Practices. Univ. of Oklahoma Press. Norman, OK.

4. Baker, A., and A. Younger. 1986. The effect of temperature on the spring growth of perennial ryegrass at three contrasting sites. Grass and Forage Sci. 41:175-178.

5. Baker, A., and A. Younger. 1987. Factors affecting the leaf extension rate of perennial ryegrass in spring. Grass and Forage Sci. 42:381-390.

6. Bryan, W., and T. Mills. 1988. Seasonality of pasture growth in West Virginia. Proceedings from the $12^{\text {th }}$ General Meeting of the European Grassland Federation, Dublin, Ireland.

7. Chapman, D.F., D. Clark, C. Land, and N. Dymock. 1983. Leaf and tiller growth of Lolium perenne and Agrostis spp. and leaf appearance rates of Trifolium repens in set stocked and rotationally grazed hill pastures. New Zealand J. Agric. Res. 26:159-168.

8. Core, E.L., E.E. Berkley, and H.A. Davis. 1944. West Virginia Grasses. West Virginia Agric. Exp. Sta. Bull. 313.

9. Dovel, R. 1996. Cutting height effects on wetland meadow forage yield and quality. J. Range Manage. 49:151-156.

10. Ebdon, J.S., and A.M. Petrovic. 1998. Morphological and growth characteristics of low- and high- water use Kentucky bluegrass cultivars. Crop Sci. 38:143-152.

11. Evans, M. 1949. Vegetative growth, development, and reproduction in Kentucky bluegrass. Ohio Agric. Exp. Sta. Res. Bull. 681. 
12. Evans, M.W., and J. Watkins. 1939. The growth of Kentucky bluegrass and of Canada bluegrass in late spring and in autumn as affected by the length of day. J. Am. Soc. Agron. 31:767-774.

13. Ghazi, H, W. van Eck, and L. Bennett. 1978. Soil Testing Methods. Soil Fertility Information Series No. 3. West Virginia University Cooperative Extension Service.

14. Harrison, C.M. 1934. Responses of Kentucky bluegrass to variation in temperature, light, cutting, and fertilizing. Plant Physiol. 9:83-106.

15. Madison, J.H. 1971. Principles of Turfgrass Culture. Van Norstrand Reinhold Co. NY.

16. Mortimer, G.B., and H.L. Ahlgren. 1936. Influence of fertilization, irrigation, and stage and height of cutting on yield and composition of Kentucky bluegrass. J. Am. Soc. Agron. 28:515-533.

17. Prince, F.S. 1956. Grassland Farming in the Humid Northeast. Van Norstrand Co. Inc. Princeton, NJ.

18. Rayburn, E.B., and S.B. Rayburn. 1998. A standardized plate meter for estimating pasture mass in on-farm research trials. Agron. J. 90:238-241.

19. Robinson, R.R., and V.G. Sprague. 1947. The clover populations and yields of a Kentucky bluegrass sod as affected by nitrogen fertilization, clipping treatments and irrigation. J. Am. Soc. Agron. 39:107-116.

20. SAS Institute. 1990. SAS/STAT user's guide. Version $6.4^{\text {th }}$ ed. SAS Inst., Cary, N.C. 


\section{$\underline{\text { Appendices }}$}

Appendix A.

\section{Kentucky Bluegrass: Sheath Splicing}

In the field experiment, an attempt was made to measure changes in psuedostem length over the growing season. Psuedostem length was measured as the distance between the ligule of the first live leaf and where the psuedostem emerged from the ground. However, many of the rates obtained for psuedostem growth were negative, indicating that it was becoming shorter. Thus, a greenhouse study was conducted to observe this phenomenon more closely.

\section{Procedure:}

Nine turf cores $\left(319 \mathrm{~cm}^{2}\right)$ were taken from block four of the field experiment on 13 June 2000. One core was taken from each plot to represent each of the treatments. All cores contained above ground growth consisting of grass and some legumes. Weeds were removed. No nitrogen was applied to the cores after they were taken. Each core was placed in a $10.2 \times 8.9 \mathrm{~cm}$ pot, lined with newspaper to fill in for the squareness of the pot. One Kentucky bluegrass tiller in each pot was tagged with a piece of colored twisty tie for observation. Tillers with bright shiny leaves and no sign of disease were chosen. All pots were watered daily. Cores were clipped according to their treatment height when they reached a recovery growth of 12.7 to $15.2 \mathrm{~cm}$. No analysis was done on clipped material. Tillers were observed once or twice a week. A sketch of each tiller was made at each observation. The length of the psuedostem, sheath length between leaves, and leaf blades were recorded and any discoloration or dead areas appearing on the leaves. From 14 June to 11 October 2000 measurements were made a total of 21 times.

\section{Results and discussion:}

Only two treatments were clipped over the four-month period. The treatment receiving $80 \mathrm{~kg} \mathrm{~N} \mathrm{ha}^{-1}$ at the $7.6 \mathrm{~cm}$ cutting height was clipped, once on 30 July and again on 28 August. The $80 \mathrm{~kg} \mathrm{~N} \mathrm{ha}^{-1}$ at the $5.1 \mathrm{~cm}$ clipping height treatment was cut on 28 August. No other treatment reached the clipping height. Of the nine tillers tagged only two died and other tillers were tagged in their place. 
The average total number of leaves that the tillers produced between June and October, including existing leaves at the start of the greenhouse experiment, was 7.1 per tiller. There was little difference among the cutting heights. Tillers from plots treated with $160 \mathrm{~kg} \mathrm{~N} \mathrm{ha}^{-1}$ produced more leaves than those from plots receiving 80 or $0 \mathrm{~kg} \mathrm{~N}$ $\mathrm{ha}^{-1}$. Evans (11) found that the number of leaves that a tiller produces depends on when the tiller began its growth. He found that tillers that began growth in the early spring produced more leaves (16.9) than those that began growth later (11.1), because the early spring tillers had more time to produce leaves. In the greenhouse experiment tillers were chosen without regard to age. The average number of new leaves that appeared per tiller from June until October was 3.8. Most new leaves were produced in July and August with 1.1 appearing per tiller each month.

The average number of green leaves present on a tiller throughout the experiment was 3.5. This result was similar to what Evans (11) found when studying vegetative growth of Kentucky bluegrass. He found an average of 3.4 green leaves per tiller at any one time over a three-year period with no clipping management. In the greenhouse experiment, the $7.6 \mathrm{~cm}$ cutting height had 3.7 green leaves present per tiller and the 2.5 and $5.1 \mathrm{~cm}$ cutting heights both had 3.3 green leaves present per tiller. The high nitrogen tillers had an average of 4.0 green leaves per tiller while the 80 and $0 \mathrm{~kg} \mathrm{~N} \mathrm{ha}^{-1}$ had less, 3.4 and 2.9, respectively. Thus, as the amount of nitrogen increased, the number of green leaves present increased.

The average leaf extension rate was $0.22 \mathrm{~cm}$ per day. As nitrogen application increased from 0 to 80 and $160 \mathrm{~kg} \mathrm{~N} \mathrm{ha}^{-1}$, the LER increased respectively from 0.17 to 0.23 and 0.26 . The LER was highest at the $7.6 \mathrm{~cm}$ cutting height $\left(0.26 \mathrm{~cm} \mathrm{~d}^{-1}\right)$ and lowest at the $5.1 \mathrm{~cm}$ height $\left(0.19 \mathrm{~cm} \mathrm{~d}^{-1}\right)$. Seasonally, the LER was highest in June at $0.31 \mathrm{~cm} \mathrm{~d}^{-1}$ and decreased to the lowest in September at $0.15 \mathrm{~cm} \mathrm{~d}^{-1}$. In October the LER increased to $0.27 \mathrm{~cm} \mathrm{~d}^{-1}$. Warm conditions in the greenhouse may have contributed to the decreasing extension rates from June to September. In June the maximum average temperature in the greenhouse was $35.6^{\circ} \mathrm{C}$. In September and October the maximum temperatures were lower at 33.1 and $27.8^{\circ} \mathrm{C}$, respectively.

In many studies the length of the leaf of grasses is measured as the distance between the tip of a new leaf and the ligule of the preceding leaf. It was measured in this 
study as the distance between the tip of a new leaf and the point from where that leaf emerged from the sheath of the preceding leaf. Measurements were taken in this way because it was found that the reason for the apparent shortening of the psuedostem was that the ligule of the youngest leaf appeared below the ligule of the preceding leaf. The youngest leaf was then emerging from the sheath and not above the ligule of the preceding leaf. This phenomenon made the psuedostem measurement shorter than before. The pulling of the leaf below the ligule of the preceding leaf, splicing open the sheath, was found a total of 14 times over the four month period, representing $41 \%$ of all new leaves appearing. This sheath splicing occurred six times on no nitrogen tillers and only four times on tillers supplied with nitrogen. There was no difference in occurrence among the heights of cuts. The average distance that the leaves pulled down below the ligule of the preceding leaf over the four months was $0.49 \mathrm{~cm}$. Leaves at the $7.6 \mathrm{~cm}$ cutting heights pulled down an average of $0.60 \mathrm{~cm}$, and the 5.1 and $2.5 \mathrm{~cm}$ cutting heights were less at 0.49 , and $0.38 \mathrm{~cm}$, respectively. Cores supplied with $160 \mathrm{~kg} \mathrm{~N} \mathrm{ha}^{-1}$ had the lowest pull down distance of $0.19 \mathrm{~cm}$. Those from $80 \mathrm{~kg} \mathrm{~N} \mathrm{ha}^{-1}$ treatments had the highest with 0.78 $\mathrm{cm}$, and the no nitrogen cores had an average distance of $0.49 \mathrm{~cm}$.

Of the 14 leaves that had their sheaths spliced by the younger leaf, nine were fully green and five were discolored or showed dead areas at the time of splicing. The major discolorations were red sheaths or leaves and yellow leaves. Of the five discolored leaves, three were from the no nitrogen treatments, one at each cutting height, and the other two were both from the $7.6 \mathrm{~cm}$ cutting height at $80 \mathrm{~kg} \mathrm{~N} \mathrm{ha}^{-1}$. The tillers with their sheaths spliced and discolored had a total of 3.2 leaves per tiller. Of the nine leaves that were green at the time of splicing it took the no nitrogen tillers 4 to 7 days to show discoloration or death and between 10 and 39 days for the tillers supplied with nitrogen. The amount of time that it took for senescence to occur after splicing of the sheaths ranged from 14 to 53 days. Spliced leaves on tillers from plots supplied with $160 \mathrm{~kg} \mathrm{~N}$ $\mathrm{ha}^{-1}$ took 43 days to reach senescence compared to the 80 and $0 \mathrm{~kg} \mathrm{~N}^{-1}$ treatments that took 22 and 35 days, respectively. Comparing the defoliation levels leaves with spliced sheaths senesced the fastest at the $2.5 \mathrm{~cm}$ cutting height (26 days) compared to 35 and 33 days at the 5.1 and $7.6 \mathrm{~cm}$ cutting heights, respectively. 
This characteristic of the leaves moving below the ligule of the preceding leaf and splicing open the sheath may be a way of separating older leaves, increasing senescence of older leaves, and keeping only young leaves present. Young leaves are more photosynthetically active then older leaves, and this may be a mechanism for ridding the tiller of older leaves. Another theory is that sheath splicing may be a response of the plant to defoliation whereby the plant maintains active growth below the defoliation level. However, this characteristic appeared in all cutting treatments, with no difference among the cutting heights. It would be of interest to investigate defoliation effects on this characteristic in the field. Harrison (14) studied the weekly regrowth of Kentucky bluegrass when cut to heights of $1.3,2.5$, and $5.1 \mathrm{~cm}$ each week. He measured the new growth above the cutting height and found that the shorter the cutting height, the shorter the amount of regrowth, indicating that the plant was adjusting its growth below the defoliation level. 


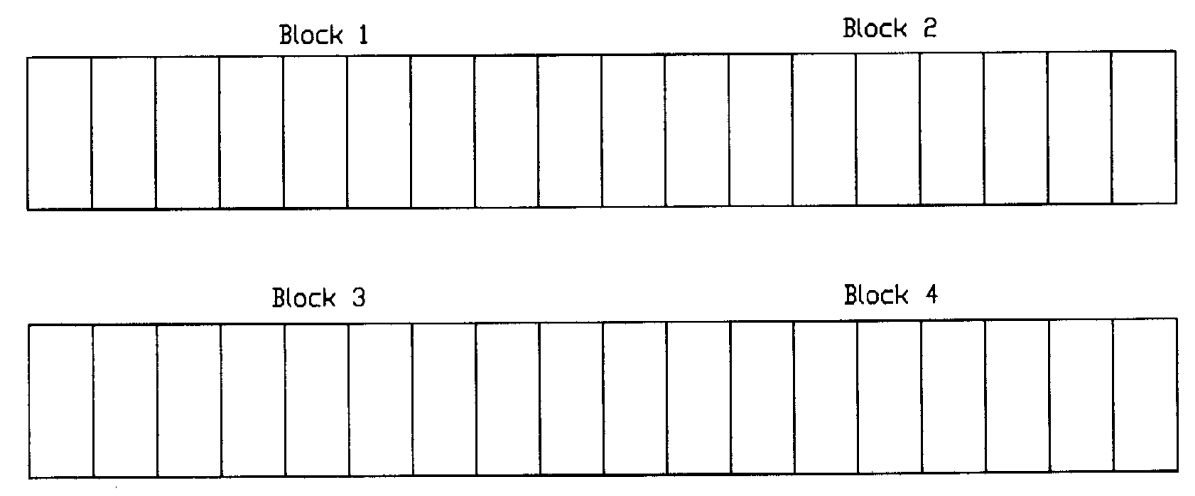

Appendix Bi Field layout of blocks 1 through 4.

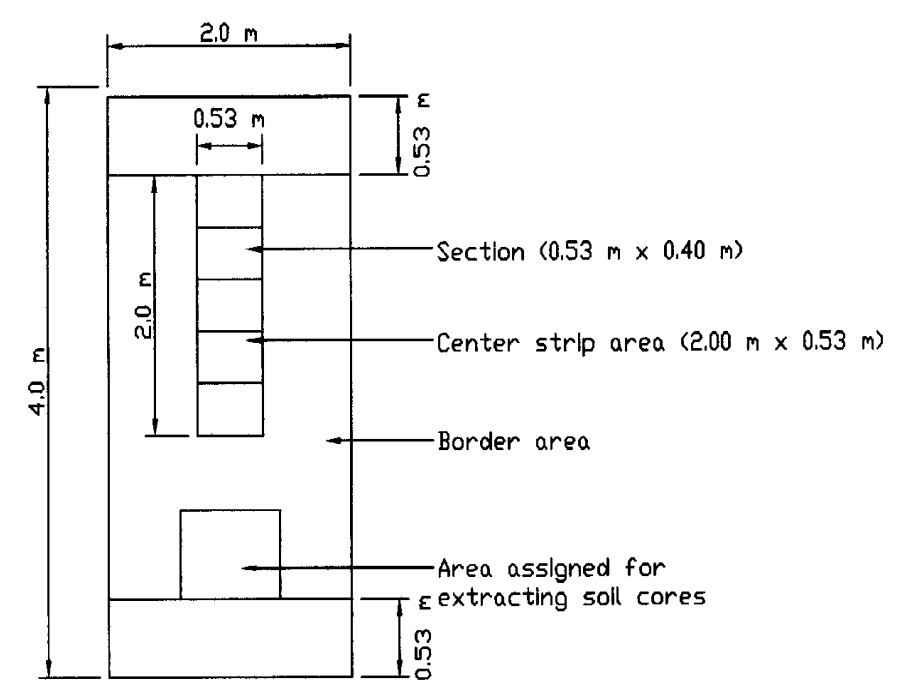

Appendix C: An example of a plot showing the center strip area and border areas. 


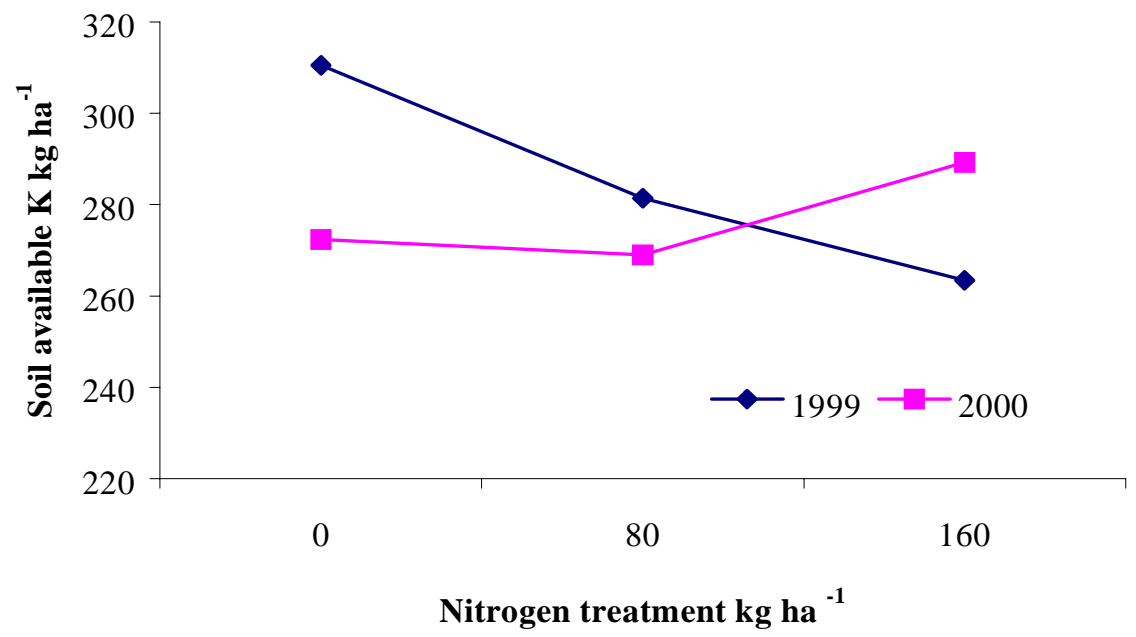

Appendix D. Soil available $\mathrm{K}$ at each nitrogen treatment for each year. The interaction between year and nitrogen treatment was significant at $\mathrm{P}<0.05$. The effects of nitrogen treatment and year were not significant.

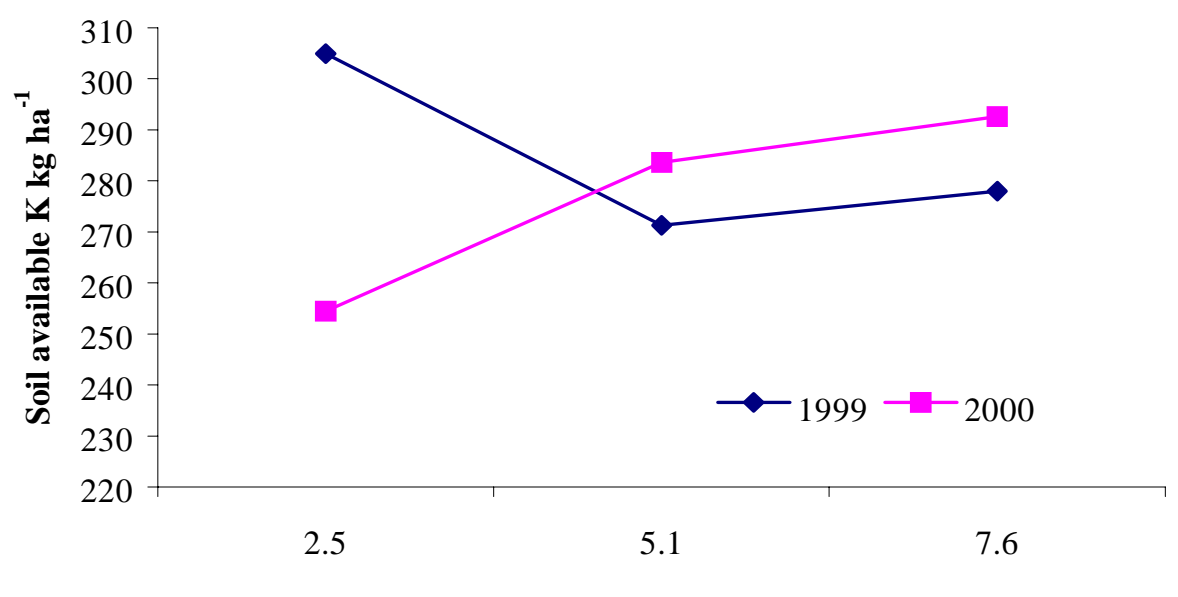

Cutting height $\mathrm{cm}$

Appendix E. Soil available $\mathrm{K}$ at each cutting height for each year. The interaction between cutting height and year was significant at $\mathrm{P}<0.001$. The effects of cutting height and year were not significant. 


\section{Appendix Table F.}

Soil analysis for cutting height, nitrogen treatment, and year (average of two sampling depths).

Cutting height

Low (L)

Medium (M)

High (H)

Significance $\dagger$

L vs. $\mathrm{M}$ and $\mathrm{H}$

M vs. H

\begin{tabular}{ccccc} 
& \multicolumn{5}{c}{ available } \\
\cline { 2 - 5 } $\mathrm{pH}$ & $\mathrm{P}$ & $\mathrm{K}$ & $\mathrm{Ca}$ & $\mathrm{Mg}$ \\
\cline { 2 - 5 } & \multicolumn{5}{c}{$\mathrm{kg} \mathrm{ha}^{-1}$} & & \\
\cline { 2 - 5 } & 57.2 & 249 & 4116 & 186 \\
6.35 & 59.8 & 248 & 4005 & 190 \\
6.34 & 60.0 & 254 & 3946 & 191 \\
$\mathrm{NS}$ & $\mathrm{NS}$ & $\mathrm{NS}$ & $\mathrm{NS}$ & $\mathrm{NS}$ \\
$\mathrm{NS}$ & $\mathrm{NS}$ & $\mathrm{NS}$ & $\mathrm{NS}$ & $\mathrm{NS}$ \\
$\mathrm{NS}$ & $\mathrm{NS}$ & $\mathrm{NS}$ & $\mathrm{NS}$ & $\mathrm{NS}$
\end{tabular}

Nitrogen treatment

$$
\begin{aligned}
& \text { No N } \\
& 80 \mathrm{~kg} \mathrm{ha}^{-1} \\
& 160 \mathrm{~kg} \mathrm{ha}^{-1}
\end{aligned}
$$

Significance

No N vs.

$\begin{array}{clllll}80 \text { and } 160 \mathrm{~kg} \mathrm{ha}^{-1} & \text { NS } & \text { NS } & \text { NS } & \text { NS } & \text { NS } \\ 80 \text { vs. } 160 \mathrm{~kg} \mathrm{ha}^{-1} & \text { NS } & \text { NS } & \text { NS } & \text { NS } & \text { NS }\end{array}$

Year

\begin{tabular}{rccccc}
1999 & 6.37 & 62.2 & 254 & 3568 & 203 \\
2000 & 6.29 & 55.8 & 247 & 4453 & 176 \\
$* *$ & $* * *$ & NS & $* * *$ & $* * *$ \\
\hline
\end{tabular}

Significance

$\begin{array}{lllll}6.35 & 60.0 & 259 & 4211 & 189\end{array}$

$\begin{array}{lllll}6.36 & 60.6 & 246 & 3989 & 186\end{array}$

$\begin{array}{lllll}6.28 & 56.3 & 247 & 3871 & 193\end{array}$

NS NS NS NS NS

$\dagger$ Significance of $\mathrm{F}$ test. NS, nonsignificant; $*, * *, * * *$, significant at the $0.05,0.01,0.001$ probability levels, respectively. 
Appendix Table G.

Analysis of variance for soil analysis

\begin{tabular}{|c|c|c|c|c|c|c|c|}
\hline \multirow[b]{2}{*}{ Source } & \multirow[b]{2}{*}{$\mathrm{df}$} & \multicolumn{2}{|l|}{$\mathrm{pH}$} & \multicolumn{2}{|l|}{$\mathrm{P}$} & \multicolumn{2}{|l|}{$\mathrm{K}$} \\
\hline & & $\mathrm{SS}$ & $\mathrm{P}$ & $\mathrm{SS}$ & $\mathrm{P}$ & SS & $\mathrm{P}$ \\
\hline Cutting height & 2 & 0.0488 & 0.7018 & 237.0 & 0.4795 & 973 & 0.9519 \\
\hline Low vs. medium and high & 1 & 0.0450 & 0.4233 & 23.5 & 0.2306 & 62 & 0.9376 \\
\hline Medium vs. high & 1 & 0.0038 & 0.8161 & 0.5 & 0.9549 & 908 & 0.7640 \\
\hline Nitrogen treatment & 2 & 0.1738 & 0.2960 & 537.5 & 0.2006 & 4173 & 0.8105 \\
\hline No N vs. 80 and $160 \mathrm{~kg} \mathrm{ha}^{-1}$ & 1 & 0.0153 & 0.6389 & 78.1 & 0.4864 & 3512 & 0.5559 \\
\hline 80 vs. $160 \mathrm{~kg} \mathrm{ha}^{-1}$ & 1 & 0.1584 & 0.1395 & 459.4 & 0.0994 & 610 & 0.8055 \\
\hline $\mathrm{N} \times \mathrm{C}$ & 4 & 0.4550 & 0.1880 & 650.2 & 0.4074 & 12303 & 0.8668 \\
\hline Error a & 24 & 1.6275 & 0.0001 & 3752.3 & 0.0001 & 236255 & 0.0001 \\
\hline Year & 1 & 0.2417 & 0.0014 & 1501.6 & 0.0001 & 3318 & 0.1712 \\
\hline $\mathrm{Nx}$ Year & 2 & 0.0143 & 0.7255 & 8.2 & 0.9235 & 12574 & 0.0310 \\
\hline C x Year & 2 & 0.0301 & 0.5098 & 60.8 & 0.5545 & 29832 & 0.0004 \\
\hline \multirow[t]{2}{*}{ Error b } & 99 & 2.1994 & 0.0001 & 5072.4 & 0.0001 & 165772 & 0.0001 \\
\hline & & \multicolumn{2}{|l|}{$\mathrm{Ca}$} & \multicolumn{2}{|l|}{$\mathrm{Mg}$} & & \\
\hline Cutting height & 2 & 640525 & 0.8117 & 458 & 0.7897 & & \\
\hline Low vs. medium and high & 1 & 499754 & 0.5719 & 432 & 0.5085 & & \\
\hline Medium vs. high & 1 & 145257 & 0.7600 & 27 & 0.8683 & & \\
\hline Nitrogen treatment & 2 & 2993297 & 0.3885 & 1656 & 0.4347 & & \\
\hline No N vs. 80 and $160 \mathrm{~kg} \mathrm{ha}{ }^{-1}$ & 1 & 2396916 & 0.2215 & 27 & 0.8677 & & \\
\hline 80 vs. $160 \mathrm{~kg} \mathrm{ha}^{-1}$ & 1 & 637097 & 0.5237 & 1635 & 0.2041 & & \\
\hline $\mathrm{N} \times \mathrm{C}$ & 4 & 4710442 & 0.5529 & 2861 & 0.5707 & & \\
\hline Error a & 24 & 36513635 & 0.2475 & 23033 & 0.0039 & & \\
\hline Year & 1 & 28377034 & 0.0001 & 26697 & 0.0001 & & \\
\hline $\mathrm{N} x$ Year & 2 & 774782 & 0.7342 & 485 & 0.5762 & & \\
\hline C x Year & 2 & 6134594 & 0.0913 & 565 & 0.5263 & & \\
\hline Error b & 95 & 118709883 & 0.0237 & 41532 & 0.0001 & & \\
\hline
\end{tabular}


Appendix Table H.

Analysis of variance for annual herbage accumulation.

\begin{tabular}{|c|c|c|c|}
\hline Source & df & $\mathrm{SS}$ & $\mathrm{P}$ \\
\hline Cutting height & 2 & 20633794 & 0.0001 \\
\hline Low vs medium and high & 1 & 20525042 & 0.0001 \\
\hline Medium vs high & 1 & 108753 & 0.6300 \\
\hline Nitrogen treatment & 2 & 1785564 & 0.1634 \\
\hline No $\mathrm{N}$ vs 80 and $160 \mathrm{~kg} \mathrm{ha}^{-1}$ & 1 & 1752690 & 0.0618 \\
\hline $80 \mathrm{vs} 160 \mathrm{~kg} \mathrm{ha}^{-1}$ & 1 & 32874 & 0.7907 \\
\hline $\mathrm{N} \times \mathrm{C}$ & 4 & 1220244 & 0.6204 \\
\hline Error a & 24 & 10958763 & 0.0503 \\
\hline Year & 1 & 75433660 & 0.0001 \\
\hline $\mathrm{N} x$ year & 2 & 1438977 & 0.0646 \\
\hline C x year & 2 & 2418419 & 0.0132 \\
\hline Error b & 27 & 6395350 & 0.0001 \\
\hline
\end{tabular}




\section{Appendix Table I.}

Herbage accumulation summed by growing period in 2000 for cutting height, nitrogen treatment, and growing period.

\begin{tabular}{|c|c|}
\hline & $\begin{array}{c}\text { Herbage } \\
\text { accumulation }\end{array}$ \\
\hline & $\mathrm{kg} \mathrm{ha}^{-1}$ \\
\hline \multicolumn{2}{|l|}{ Cutting height } \\
\hline Low $(\mathrm{L})$ & 1674 \\
\hline Medium (M) & 1148 \\
\hline $\operatorname{High}(\mathrm{H})$ & 1186 \\
\hline Significance $\dagger$ & $* * *$ \\
\hline L vs. $\mathrm{M}$ and $\mathrm{H}$ & $* * *$ \\
\hline M vs. H & NS \\
\hline \multicolumn{2}{|l|}{ Nitrogen treatment } \\
\hline No N & 1328 \\
\hline $80 \mathrm{~kg} \mathrm{ha}^{-1}$ & 1361 \\
\hline $160 \mathrm{~kg} \mathrm{ha}^{-1}$ & 1320 \\
\hline Significance & NS \\
\hline No N vs. & \\
\hline 80 and $160 \mathrm{~kg} \mathrm{ha}^{-1}$ & NS \\
\hline 80 vs. $160 \mathrm{~kg} \mathrm{ha}^{-1}$ & NS \\
\hline
\end{tabular}

Growing period

$\begin{array}{lc}\text { Spring } & 1648 \\ \text { Summer } & 1471 \\ & 890\end{array}$

Significance

$\dagger$ Significance of $\mathrm{F}$ test. NS, nonsignificant; *, **, ***, significant at the $0.05,0.01,0.001$ probability levels, respectively.

The interaction between cutting height and growing period was significant at $\mathrm{P}<0.001$. 


\section{Appendix Table J.}

Analysis of variance for herbage accumulation summed by growing period in 2000 .

\begin{tabular}{|c|c|c|c|}
\hline Source & df & SS & $\mathrm{P}$ \\
\hline Cutting height & 2 & 6195762 & 0.0001 \\
\hline Low vs medium and high & 1 & 6169331 & 0.0001 \\
\hline Medium vs high & 1 & 26430 & 0.7221 \\
\hline Nitrogen treatment & 2 & 33811 & 0.9207 \\
\hline No N vs 80 and $160 \mathrm{~kg} \mathrm{ha}^{-1}$ & 1 & 3716 & 0.8938 \\
\hline 80 vs $160 \mathrm{~kg} \mathrm{ha}^{-1}$ & 1 & 30095 & 0.7043 \\
\hline $\mathrm{N} \times \mathrm{C}$ & 4 & 1651450 & 0.1231 \\
\hline Error a & 24 & 4897137 & 0.0236 \\
\hline Period & 2 & 11327370 & 0.0001 \\
\hline $\mathrm{N} x$ period & 4 & 193477 & 0.7675 \\
\hline $\mathrm{C} \times$ period & 4 & 4317637 & 0.0001 \\
\hline Error b & 54 & 5726249 & 0.0001 \\
\hline
\end{tabular}




\section{Appendix Table K.}

Effects of cutting height, nitrogen treatment, year, and growing period on botanical composition estimated from hand separation dry weights.

\begin{tabular}{|c|c|c|c|c|}
\hline & Legume & Grass & Weed & Dead \\
\hline \multicolumn{5}{|l|}{ Cutting height } \\
\hline Low & 19 & 67 & 10 & 4.0 \\
\hline Medium & 11 & 73 & 12 & 5.0 \\
\hline High & 23 & 64 & 11 & 2.0 \\
\hline Significance $\dagger$ & $* * *$ & * & NS & *** \\
\hline \multicolumn{5}{|l|}{ Nitrogen treatment } \\
\hline No $\mathrm{N}$ & 21 & 63 & 12 & 4.0 \\
\hline $80 \mathrm{~kg} \mathrm{ha}^{-1}$ & 19 & 68 & 10 & 3.0 \\
\hline $160 \mathrm{~kg} \mathrm{ha}^{-1}$ & 15 & 71 & 11 & 3.0 \\
\hline Significance & NS & NS & NS & NS \\
\hline \multicolumn{5}{|l|}{ Year } \\
\hline 1999 & 14 & 73 & 8 & 5.0 \\
\hline 2000 & 26 & 59 & 15 & 0.2 \\
\hline Significance & * & $* *$ & NS & $* *$ \\
\hline \multicolumn{5}{|l|}{ Growing period } \\
\hline Spring & 15 & 75 & 9 & 0.9 \\
\hline Summer & 25 & 58 & 14 & 4.0 \\
\hline Lt. sum/fall & 15 & 67 & 11 & 8.0 \\
\hline Significance & $* *$ & $* * *$ & NS & $* * *$ \\
\hline
\end{tabular}

$\dagger$ Significance of F test. NS, nonsignificant; *, **, ***, significant at the $0.05,0.01,0.001$ probability levels, respectively. 
Appendix Table L.

Analysis of variance for botanical composition, estimated using dry weights.

\begin{tabular}{|c|c|c|c|c|c|c|c|c|c|}
\hline \multirow[b]{2}{*}{ Source } & \multirow[b]{2}{*}{$\mathrm{df}$} & \multicolumn{2}{|c|}{ Legume } & \multicolumn{2}{|c|}{ Grass } & \multicolumn{2}{|c|}{ Weed } & \multicolumn{2}{|c|}{ Dead } \\
\hline & & SS & $\mathrm{P}$ & SS & $\mathrm{P}$ & SS & $\mathrm{P}$ & SS & $\mathrm{P}$ \\
\hline Cutting height & 2 & 4925 & 0.0006 & 2547 & 0.0757 & 26 & 0.9190 & 608 & 0.0001 \\
\hline Nitrogen treatment & 2 & 39 & 0.9032 & 383 & 0.6347 & 160 & 0.5972 & 77 & 0.0630 \\
\hline $\mathrm{N} \times \mathrm{C}$ & 4 & 727 & 0.4587 & 883 & 0.7082 & 336 & 0.6954 & 96 & 0.1308 \\
\hline Error a & 24 & 7677 & 0.2361 & 7211 & 0.4490 & 5023 & 0.0163 & 994 & 0.2835 \\
\hline Year & 1 & 1490 & 0.0140 & 2345 & 0.0310 & 496 & 0.0907 & 155 & 0.0024 \\
\hline $\mathrm{N} x$ Year & 2 & 155 & 0.6719 & 523 & 0.5417 & 124 & 0.6689 & 17 & 0.4806 \\
\hline Cx Year & 2 & 215 & 0.5792 & 612 & 0.4904 & 287 & 0.4089 & 69 & 0.0783 \\
\hline Error b & 14 & 2648 & 0.7222 & 5713 & 0.1848 & 2103 & 0.1650 & 158 & 0.9878 \\
\hline Period & 2 & 2608 & 0.0090 & 6658 & 0.0001 & 421 & 0.1423 & 1143 & 0.0001 \\
\hline $\mathrm{N} \times$ Period & 4 & 871 & 0.4957 & 667 & 0.6848 & 117 & 0.8898 & 10 & 0.9894 \\
\hline $\mathrm{C} \times$ Period & 3 & 1294 & 0.1782 & 422 & 0.6964 & 863 & 0.0504 & 440 & 0.0089 \\
\hline Error c & 57 & 14496 & 0.0040 & 16651 & 0.0022 & 5944 & 0.0284 & 1973 & 0.0100 \\
\hline
\end{tabular}




\section{Appendix Table M.}

Effects of cutting height, nitrogen treatment, year and growing period on botanical composition estimated from hand separation leaf area.

\begin{tabular}{|c|c|c|c|c|}
\hline & Legume & Grass & Weed & Dead \\
\hline \multirow{2}{*}{\multicolumn{5}{|c|}{ Cutting height }} \\
\hline Low & 20 & & & \\
\hline Medium & 12 & 70 & 12 & s \\
\hline viedium & 12 & 10 & 13 & 6 \\
\hline High & 24 & 65 & 10 & 2 \\
\hline Significance $\dagger$ & $* *$ & NS & NS & $* * *$ \\
\hline \multicolumn{5}{|l|}{ Nitrogen treatment } \\
\hline No N & 21 & 62 & 13 & 4 \\
\hline $80 \mathrm{~kg} \mathrm{ha}^{-1}$ & 19 & 66 & 10 & 4 \\
\hline $160 \mathrm{~kg} \mathrm{ha}^{-1}$ & 18 & 69 & 11 & 3 \\
\hline Significance & NS & NS & NS & NS \\
\hline \multicolumn{5}{|l|}{ Year } \\
\hline 1999 & 15 & 70 & 9 & 6 \\
\hline 2000 & 26 & 58 & 15 & 0 \\
\hline Significance & $*$ & $*$ & $*$ & $*$ \\
\hline \multicolumn{5}{|l|}{ Growing periods } \\
\hline Spring & 18 & 70 & 11 & 1 \\
\hline Summer & 25 & 58 & 13 & 5 \\
\hline Lt. sum/fall & 15 & 67 & 9 & 9 \\
\hline Significance & $*$ & $* *$ & NS & $* * *$ \\
\hline
\end{tabular}


Appendix Table N.

Analysis of variance for botanical composition, estimated using leaf area.

\begin{tabular}{|c|c|c|c|c|c|c|c|c|c|}
\hline \multirow[b]{2}{*}{ Source } & \multirow[b]{2}{*}{$\mathrm{df}$} & \multicolumn{2}{|c|}{ Legume } & \multicolumn{2}{|c|}{ Grass } & \multicolumn{2}{|c|}{ Weed } & \multicolumn{2}{|c|}{ Dead } \\
\hline & & SS & $\mathrm{P}$ & SS & $\mathrm{P}$ & SS & $\mathrm{P}$ & SS & $\mathrm{P}$ \\
\hline Cutting height & 2 & 4989 & 0.0016 & 2102 & 0.0595 & 18 & 0.8965 & 957 & 0.0002 \\
\hline Nitrogen treatment & 2 & 39 & 0.9211 & 233 & 0.6875 & 90 & 0.5943 & 128 & 0.1471 \\
\hline $\mathrm{N} \times \mathrm{C}$ & 4 & 1235 & 0.3118 & 671 & 0.6991 & 401 & 0.3509 & 122 & 0.4162 \\
\hline Error a & 24 & 8919 & 0.1969 & 7895 & 0.4657 & 3150 & 0.0621 & 1310 & 0.3818 \\
\hline Year & 1 & 1163 & 0.0428 & 1706 & 0.0324 & 493 & 0.0286 & 217 & 0.0159 \\
\hline $\mathrm{N} x$ Year & 2 & 143 & 0.7419 & 119 & 0.8241 & 10 & 0.9422 & 23 & 0.6792 \\
\hline Cx Year & 2 & 463 & 0.3975 & 1509 & 0.1183 & 476 & 0.0902 & 147 & 0.1139 \\
\hline Error b & 14 & 3285 & 0.6329 & 4235 & 0.5312 & 1161 & 0.4251 & 405 & 0.8709 \\
\hline Period & 2 & 2227 & 0.0249 & 4239 & 0.0028 & 269 & 0.1932 & 1635 & 0.0001 \\
\hline $\mathrm{N} x$ Period & 4 & 1062 & 0.4473 & 1144 & 0.4810 & 47 & 0.9635 & 81 & 0.8041 \\
\hline C x Period & 3 & 470 & 0.6470 & 1147 & 0.3263 & 858 & 0.0188 & 798 & 0.0027 \\
\hline Error c & 56 & 15800 & 0.0127 & 18498 & 0.0166 & 4444 & 0.0309 & 2852 & 0.0033 \\
\hline
\end{tabular}




\section{Appendix Table $\mathrm{O}$.}

Leaf extension rate, leaf appearance rate, tiller density, and visually estimated percent clover for cutting height, nitrogen treatment, year, growing period, and leaf extension category.

\begin{tabular}{|c|c|c|c|c|c|}
\hline & & LER & LAR & $\begin{array}{c}\text { Tiller } \\
\text { density }\end{array}$ & Clover \\
\hline & & $\mathrm{cm} \mathrm{d}^{-1}$ & leaves $\mathrm{d}^{-1}$ & tillers $\mathrm{m}^{-2}$ & $\%$ \\
\hline \multicolumn{6}{|l|}{ Cutting height } \\
\hline & Low (L) & 0.30 & 0.060 & 6836 & 31 \\
\hline & Medium (M) & 0.31 & 0.051 & 7845 & 19 \\
\hline \multirow{4}{*}{ Significance $\dagger$} & $\operatorname{High}(\mathrm{H})$ & 0.34 & 0.056 & 7363 & 23 \\
\hline & & NS & $* *$ & NS & $*$ \\
\hline & $\mathrm{L}$ vs. $\mathrm{M}$ and $\mathrm{H}$ & NS & $*$ & NS & $*$ \\
\hline & M vs. $\mathrm{H}$ & NS & NS & NS & NS \\
\hline \multicolumn{6}{|c|}{ Nitrogen treatment } \\
\hline & No N & 0.30 & 0.056 & 6418 & 30 \\
\hline & $80 \mathrm{~kg} \mathrm{ha}{ }^{-1}$ & 0.34 & 0.056 & 8031 & 19 \\
\hline & $160 \mathrm{~kg} \mathrm{ha}^{-1}$ & 0.31 & 0.056 & 7596 & 24 \\
\hline \multirow[t]{4}{*}{ Significance } & & NS & NS & $*$ & NS \\
\hline & No N vs. & & & & \\
\hline & 80 and $160 \mathrm{~kg} \mathrm{ha}^{-1}$ & NS & NS & $* *$ & $*$ \\
\hline & $80 \mathrm{vs} .160 \mathrm{~kg} \mathrm{ha}^{-1}$ & NS & NS & NS & NS \\
\hline \multicolumn{6}{|l|}{ Year } \\
\hline & 1999 & 0.30 & 0.055 & 3833 & . \\
\hline & 2000 & 0.41 & 0.057 & 10546 & . \\
\hline Significance & & $* * *$ & NS & $* * *$ & . \\
\hline \multicolumn{6}{|c|}{ Growing period } \\
\hline \multirow{7}{*}{ Significance } & Spring & 0.32 & 0.052 & 7103 & . \\
\hline & Summer & 0.27 & 0.048 & 6648 & . \\
\hline & Lt. summer/early fall & 0.38 & 0.067 & 8335 & . \\
\hline & & $* * *$ & $* * *$ & $*$ & . \\
\hline & Spring vs. Summer & & & & \\
\hline & lt. summer/early fall & $*$ & . & . & . \\
\hline & $\begin{array}{l}\text { Summer vs. lt summer/ } \\
\text { early fall }\end{array}$ & $* * *$ & · & . & $\cdot$ \\
\hline \multicolumn{6}{|l|}{ LER category } \\
\hline & Category 1 & 0.39 & . & . & . \\
\hline & Category 2 & 0.35 & . & . & . \\
\hline & Category 3 & 0.24 & . & . & . \\
\hline \multirow[t]{3}{*}{ Significance } & & $* * *$ & . & . & . \\
\hline & Category 1 vs. 2 and 3 & $* * *$ & . & . & . \\
\hline & Category 2 vs. 3 & $* * *$ & & & \\
\hline
\end{tabular}

$\dagger$ Significance of F test. NS, nonsignificant; $* * *, * * *$, significant at the $0.05,0.01,0.001$ probability levels, respectively. 
Appendix Table P.

Analysis of variance of visually estimated percent clover.

\begin{tabular}{|c|c|c|c|}
\hline Source & $\mathrm{df}$ & SS & $\underline{P}$ \\
\hline Cutting height & 2 & 966 & 0.0320 \\
\hline Low vs medium and high & 1 & 889 & 0.0122 \\
\hline Medium vs high & 1 & 77 & 0.4330 \\
\hline Nitrogen treatment & 2 & 683 & 0.0796 \\
\hline No N vs 80 and $160 \mathrm{~kg} \mathrm{ha}^{-1}$ & 1 & 517 & 0.0497 \\
\hline $80 \mathrm{vs} 160 \mathrm{~kg} \mathrm{ha}^{-1}$ & 1 & 165 & 0.2541 \\
\hline $\mathrm{N} \times \mathrm{C}$ & 4 & 1455 & 0.0384 \\
\hline Error a & 24 & 2907 & 0.0049 \\
\hline
\end{tabular}


Appendix Table Q.

Analysis of variance for leaf extension rate.

\begin{tabular}{|c|c|c|c|}
\hline Source & $\mathrm{df}$ & $\mathrm{SS}$ & $\mathrm{P}$ \\
\hline Cutting height & 2 & 0.2840 & 0.0783 \\
\hline Low vs medium and high & 1 & 0.0779 & 0.4841 \\
\hline Medium vs high & 1 & 0.2083 & 0.2567 \\
\hline Nitrogen treatment & 2 & 0.1690 & 0.2075 \\
\hline No $\mathrm{N}$ vs 80 and $160 \mathrm{~kg} \mathrm{ha}^{-1}$ & 1 & 0.0493 & 0.5772 \\
\hline $80 \mathrm{vs} 160 \mathrm{~kg} \mathrm{ha}^{-1}$ & 1 & 0.1200 & 0.3867 \\
\hline $\mathrm{N} \times \mathrm{C}$ & 4 & 0.4670 & 0.0843 \\
\hline Error a & 24 & 3.7031 & 0.0001 \\
\hline Year & 1 & 2.4710 & 0.0001 \\
\hline $\mathrm{N} x$ Year & 2 & 0.1760 & 0.1952 \\
\hline C x Year & 2 & 0.0410 & 0.6735 \\
\hline Error b & 27 & 1.3692 & 0.3855 \\
\hline Period & 2 & 2.7760 & 0.0001 \\
\hline Period 1 vs 2 and 3 & 1 & 0.1861 & 0.0453 \\
\hline Period 2 vs 3 & 1 & 2.7486 & 0.0001 \\
\hline $\mathrm{N} x$ Period & 4 & 0.7820 & 0.0027 \\
\hline $\mathrm{C} \times$ Period & 4 & 0.6510 & 0.0090 \\
\hline Error c & 1685 & 80.8678 & 0.0001 \\
\hline Category & 2 & 4.9250 & 0.0001 \\
\hline Category 1 vs 2 and 3 & 1 & 2.7282 & 0.0001 \\
\hline Category 2 vs 3 & 1 & 2.1476 & 0.0001 \\
\hline Error a & 6 & 0.0931 & 0.9186 \\
\hline
\end{tabular}


Appendix Table R.

Analysis of variance for leaf appearance rate and tiller density.

\begin{tabular}{|c|c|c|c|c|c|}
\hline \multirow[b]{2}{*}{ Source } & \multirow[b]{2}{*}{ df } & \multicolumn{2}{|c|}{ Leaf appearance rate } & \multicolumn{2}{|c|}{ Tiller density } \\
\hline & & SS & $\mathrm{P}$ & SS & $\mathrm{P}$ \\
\hline Cutting height & 2 & 0.00240 & 0.0067 & 34556767 & 0.2120 \\
\hline Low vs medium and high & 1 & 0.00160 & 0.0268 & 22971445 & 0.1457 \\
\hline Medium vs high & 1 & 0.00080 & 0.1132 & 10867871 & 0.3113 \\
\hline Nitrogen treatment & 2 & 0.00000 & 0.9297 & 102410237 & 0.0156 \\
\hline No $N$ vs 80 and $160 \mathrm{~kg} \mathrm{ha}^{-1}$ & 1 & 0.00000 & 0.8712 & 96594369 & 0.0051 \\
\hline 80 vs $160 \mathrm{~kg} \mathrm{ha}^{-1}$ & 1 & 0.00000 & 0.7895 & 5805083 & 0.4571 \\
\hline $\mathrm{N} \times \mathrm{C}$ & 4 & 0.00220 & 0.0519 & 20071607 & 0.7519 \\
\hline Error a & 24 & 0.00709 & 0.6836 & 243857264 & 0.3583 \\
\hline Year & 1 & 0.00020 & 0.3339 & 2172757046 & 0.0001 \\
\hline $\mathrm{N} x$ Year & 2 & 0.00010 & 0.8737 & 37370150 & 0.1882 \\
\hline Cx Year & 2 & 0.00140 & 0.0457 & 27921310 & 0.2817 \\
\hline Error b & 27 & 0.00543 & 0.9538 & 283758829 & 0.3140 \\
\hline Period & 2 & 0.01450 & 0.0001 & 87842399 & 0.0105 \\
\hline $\mathrm{N} x$ Period & 4 & 0.00090 & 0.6237 & 22730749 & 0.6537 \\
\hline $\mathrm{C} \times$ Period & 4 & 0.00070 & 0.7423 & 74379323 & 0.0980 \\
\hline Error c & 126 & 0.04443 & 0.1824 & 1074438569 & 0.0001 \\
\hline
\end{tabular}




\title{
Vita \\ Beverly Sedon \\ Moundsville, WV
}

\author{
EDUCATION \\ July 1998 - May 2001 \\ Master of Science in Agronomy \\ Major in Crops Agronomy \\ West Virginia University Morgantown, West Virginia \\ Thesis: $\quad$ Effects of three clipping managements on growth and \\ production of a Kentucky bluegrass-clover sward.
}

August 1993 - May 1998

Bachelor of Science in Agriculture

Major in Environmental Protection

West Virginia University Morgantown, West Virginia

\section{EMPLOYMENT}

June 1998 - December 2000

Graduate Research Assistant,

Division of Plant and Soil Sciences

WVU Morgantown, WV 